\title{
El arquitecto tardogótico Juan de Acha en La Rioja: 1528- 1558
}

\section{The Late Gothic architect Juan de Acha in La Rioja: 1528- 1558}

\author{
Aurelio Á. Barrón García \\ Universidad de Cantabria \\ Departamento de Historia moderna y contemporánea \\ Facultad de Filosofía y Letras. Edificio Interfacultativo \\ Avda. de los Castros, 52. 39005 - Santander \\ barrona@unican.es \\ ORCID: https://orcid.org/ 0000-0002-7608-5923
}

Fecha de envío: 10/09/2018 Aceptado: 19/10/2018.

Referencia: Santander. Estudios de Patrimonio, 1 (2018), pp. 69-120.

ISSN 2605-4450 (ed. impresa) / ISSN 2605-5317 (digital)

Este trabajo se enmarca en el Proyecto de investigación I+D del Ministerio de Economía, Industria y Competitividad HAR2016-77254-P

Resumen: A partir de nueva documentación se presenta la obra del arquitecto tardogótico Juan de Acha, natural de Ispáster en el Señorío de Vizcaya. En sus obras de Tricio, Nájera, Entrena, El Cortijo y Logroño se manifiesta seguidor de la arquitectura de Martín Ruiz de Álbiz y San Juan de Arteaga, aunque seguramente se formó con Martín de Vergara. Contribuyó de modo decisivo a la difusión de las bóvedas estrelladas formadas con terceletes curvos y combados.

Palabras clave: Arquitectura; Tardogótico; España; Castilla; La Rioja; siglo XVI; Juan de Acha; Martín de Vergara.

\begin{abstract}
This paper contains the analysis of new documentation related with the work of the Late Gothic architect Juan de Acha, native from Ispáster in the Lordship of Biscay. His buildings in Tricio, Nájera, Entrena, El Cortijo and Logroño demonstrate that he was a follower of the architecture of Martín Ruiz de Álbiz and San Juan de Arteaga although he was probably trained by Martín de Vergara. He contributed decisively to the diffusion of the vaults formed with figures of stars and the curved-rib vault with curved tiercerons.
\end{abstract}

Keywords: Architecture; Late Gothic; Spain; Castille; La Rioja; 16th century; Juan de Acha; Martín de Vergara. 


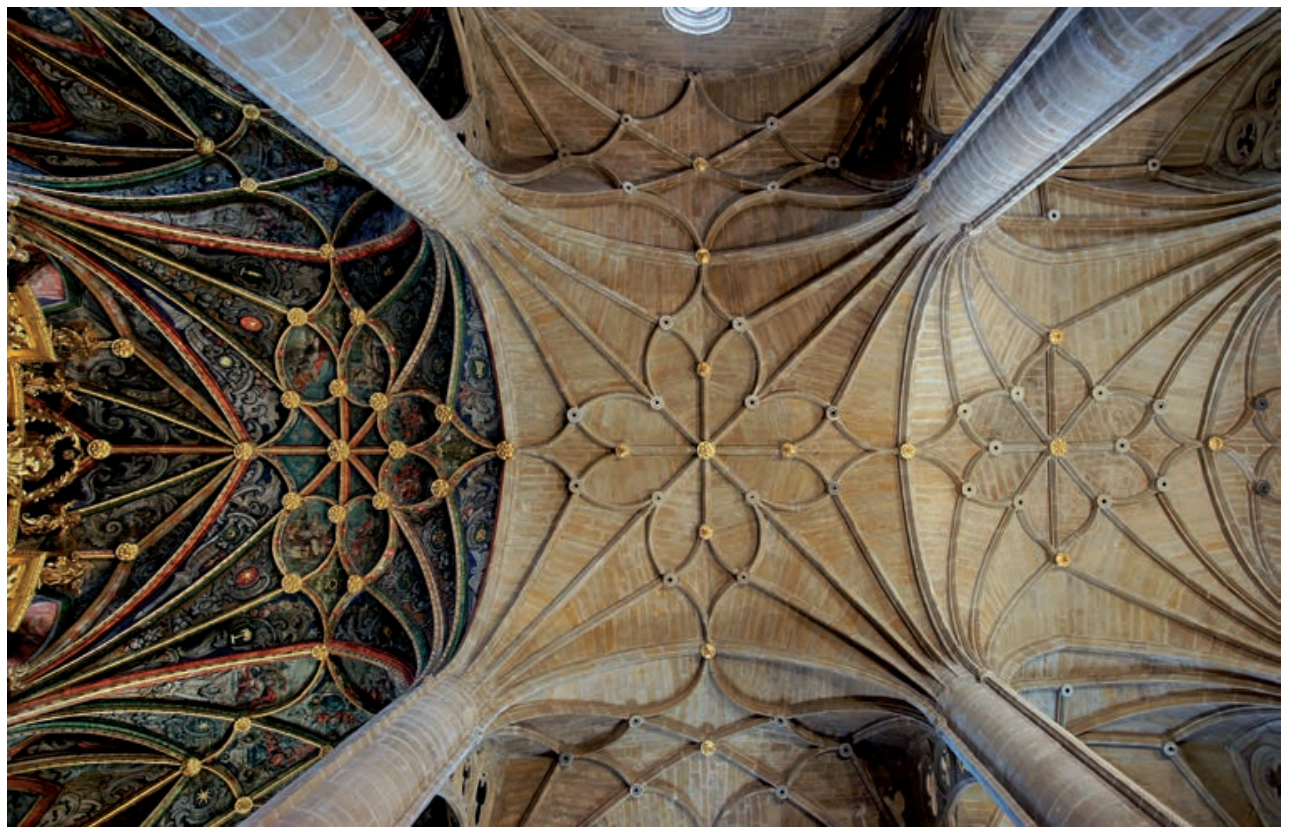

Fig. 1. Bóvedas estrelladas. Martín Ruiz de Álbiz y San Juan de Arteaga. 1523-1529. Colegiata de Santa María la Redonda. Logroño (La Rioja)

La edificación del convento de la Piedad en Casalarreina - levantado de 1514 a $1522-$, fue un hito fundamental en la arquitectura del Tardogótico en La Rioja ${ }^{1}$ (Fig. 1). Aquí aparecieron los abovedamientos con terceletes curvos y combados que se generalizaron en las obras construidas en La Rioja Alta durante la primera mitad del siglo XVI. Juan de Rasines, que hubo de dirigir las obras de Casalarreina junto con Felipe Bigarny, recreó los combados presentes en el convento de Casalarreina en los abovedamientos realizados en el claustro de los caballeros de Santa María la Real de Nájera, en el convento de San Miguel del Monte de la Morcuera y en las cabeceras de la catedral de San-

1 BARRÓN GARCÍA, Aurelio Á., "Primeras obras en La Rioja del arquitecto Juan de Rasines, 1469-1542", Boletín del Museo e Instituto Camón Aznar (BMICA), 110 (2012), pp. 48-57. BARRÓN GARCÍA, Aurelio Á., “Bóvedas con figuras de estrellas y combados del Tardogótico en La Rioja”, Turiaso, XXI (2012-2013), pp. 238-240; BARRÓN GARCÍA, Aurelio Á., "Martín Ruiz de Álbiz y San Juan de Arteaga, arquitectos de la catedral de Santa María la Redonda en Logroño (1523-1529)", Goya, 353 (2015), p. 265. En estas publicaciones se encontrará mención de otra bibliografía sobre el convento de la Piedad. 
to Domingo de la Calzada y de la iglesia de Santo Tomás de Haro. Hemos defendido que en Casalarreina también debieron participar San Juan de Arteaga y Martín Ruiz de Álbiz. Arteaga realizó una variante del diseño de la bóveda del crucero del convento de Casalarreina en la iglesia parroquial de Leiva que estaba edificada o en proceso de conclusión en 1523. Martín Ruiz de Álbiz, discípulo de Simón de Colonia, que también hubo de trabajar en Casalarreina, realizó con combados la bóveda del sotacoro de la iglesia de Zarratón, concluida para 1520. Además, en 1519 Ruiz de Álbiz introdujo el diseño de combados en Logroño en una traza para la iglesia de Santiago que finalmente no ejecutó. Junto con su primo San Juan de Arteaga, levantó la nueva iglesia de Santa María la Redonda en Logroño que fue trascendental para la consolidación y difusión de los abovedamientos con terceletes curvos y combados en La Rioja. En esta colegial, proyectado y edificado su abovedamiento entre 1523 y 1529, aparecen las bóvedas de diecisiete claves y treinta y dos combados que, más adelante, emplearon Juan de Acha y Juan Pérez de Solarte. En este tipo de bóveda, los combados dibujan círculos y, si se siguen las líneas de los conopios, componen formas acorazonadas que, en torno al polo, delimitan una rueda de lados cóncavos. En la colegial de la Redonda, como la bóveda de la capilla mayor está ligada al ochavo del ábside, encontramos que las crucerías únicamente representan tres formas acorazonadas dirigidas hacia los arcos formeros laterales y hacia el arco toral, pues se sustituye el cuarto corazón por nervios para cubrir el ochavo de la cabecera. Con una solución semejante Juan de Rasines cerró una de las capillas de esquina del claustro de los caballeros de Nájera² ${ }^{2}$, aunque cuenta con trece claves porque carecen de ellas las intersecciones de los combados con los cruceros.

\section{Datos biográficos}

Juan de Acha (c. 1497-1558) declaró en 1552 que tenía 55 años, de modo que, si acertó en la testificación, había nacido en $1497^{3}$. En un pleito

2 BARRÓN GARCÍA, Aurelio Á., "Sobre las obras de madurez del arquitecto tardogótico Juan de Rasines", Berceo, 162 (2012), pp. 242-246. Las bóvedas del claustro de los caballeros muestran un repertorio de estrellas fundamental para la evolución del Tardogótico en la zona.

3 MOYA VALGAÑÓN, José Gabriel, Arquitectura religiosa del siglo XVI en La Rioja 
para la averiguación de hidalguía que los hermanos Juan y Martín de Acha mantuvieron con el concejo de Baños de Río Tobía, donde se habían casado y residían, se señaló que habían llegado a esta localidad riojana hacía 14 o 15 años cuando contaban con 18 o 20 años de edad ${ }^{4}$. Buscaban salir del padrón de pecheros en el que el concejo los había incluido. Como Juan de Acha señaló en la primera testificación comentada que había nacido en 1497 se puede apuntar que había llegado a Baños de Río Tobía hacía 1515 o 1517 y podemos datar el pleito para demostrar su hidalguía en 1529 o 1530, aunque tal vez fuera un poco posterior, pues Martín de Acha declaró en otra ocasión haber nacido en $1506^{5}$.

El pleito contra el concejo de Baños nos informa que los Acha eran naturales de Ispáster en el Señorío de Vizcaya. Aunque originarios del solar hidalgo de Acha, nuestro cantero vivió su infancia en el solar de Eguen, también de la anteiglesia de San Miguel de Ispáster, que

Alta, Logroño, Instituto de Estudios Riojanos (IER), 1980, T. II, p. 31. Se traza una primera biografía de Juan de Acha y de sus hermanos Martín y Pedro de Acha, en MOYA VALGAÑÓN, José Gabriel, Arquitectura religiosa..., T. I, pp. 91-92; BARRIO LOZA, José Ángel y MOYA VALGANÓN, José Gabriel, “Los canteros vizcaínos (1500-1800). Diccionario biográfico", Kobie, 11 (1981), pp. 176-177; SAN MARTÍN ASCACÍBAR, Luis, La actividad artística en La Rioja durante el siglo XVI, Logroño, IER, 2005. Tanto Juan de Acha como su hijo Pedro Martínez de Acha firmaron con hache en el apellido: Hacha. Sin embargo, Pedro de Acha, hermano de Juan, firmó siempre sin hache. Por su parte, Martín de Acha declaró en 1539 que no sabía firmar; Archivo Histórico Provincial de La Rioja (AHPLR); Cristóbal Rodríguez, 1538-1539, prot. 474, f. $367 \mathrm{r}$.

4 Real Academia de la Historia. Colección Salazar y Castro, M-141, ff. 148-149v, no inventario 58538. Publicado en, BARRIO LOZA, José Ángel y MOYA VALGAÑÓN, José Gabriel, “El modo vasco de producción arquitectónica en los siglos XVI-XVIII", Kobie, 10 (1980), pp. 322-323. Los padres de Juan y Martín de Acha se llamaron Juan de Acha y Domenja y ya eran difuntos en el momento de la averiguación de hidalguía. Los abuelos se denominaron Juan de Acha y María. El padre y el abuelo vivieron en el solar de Acha. Todos ellos defendieron en el pleito que eran hidalgos de solar conocido. Desconocemos si alguno guarda relación con el escultor Juan de Acha que firmó al pie de la escultura de San Bartolomé en el portal del monasterio de San Bartolomé de Olaso en Elgoibar.

5 Martín de Acha en 1552 declaró tener 46 años en la probanza presentada por Juan Pérez de Solarte sobre la edificación de la iglesia de San Andrés de Anguiano; Archivo de la Real Chancillería de Valladolid (ARCHV), Pl. Civiles, Quevedo (F), C.733.3, BARRÓN GARCÍA, Aurelio Á., "La obra del arquitecto tardogótico Juan Pérez de Solarte en Anguiano y Nájera (La Rioja)", Berceo, 174 (2018), pp. 69-88. 
pertenecía a su madre Domenja; lugar donde se había instalado su padre al contraer matrimonio y salir, simultáneamente, del solar paterno que tuvo ocupado su abuelo hasta su defunción. A pesar de lo que interesadamente sostuvieron los hermanos Acha en la averiguación de hidalguía, Juan de Acha mantuvo su vecindad en Ispáster mucho tiempo y al contratar la capilla mayor de la iglesia de Tricio en 1528 se declaró vecino de la citada localidad vizcaína ${ }^{6}$, de modo que, aunque viviera en Baños de Río Tobía para atender las obras que contrató en la zona de Nájera, no residiría permanentemente hasta contraer matrimonio - con Catalina González, con posterioridad a 1528 - y entonces sería cuando el concejo lo introdujo en el padrón como un pechero más.

En cualquier caso, en 1538 había tomado vecindad en Logroño donde se mantuvo hasta el final de sus días, ocurrido a últimos de $1558^{7}$ o un poco después. El deceso aconteció en su lugar de origen según lo manifestaron los vecinos de Entrena en 1562 durante el pleito que mantuvieron con sus herederos por la tasación y finalización de la iglesia parroquial ${ }^{8}$. Con anterioridad, en Logroño llegaron a vivir los tres hermanos Acha: Juan, Martín y Pedro. También la madre fue residente en la capital del Ebro y dejó una cantidad para la edificación del retablo de Santa María de Palacio9. Juan de Acha estuvo casado con Catalina González y tuvo dos hijos: Pedro Martínez de Acha, que continuó con el oficio de cantero, y Magdalena González desposada con Pedro González de Belorado. Magdalena falleció antes que su padre y fue enterrada en la colegial de la Redonda de Logroño. Poco

6 ARCHV, Pl. Civiles, Fernando Alonso (F), C. 907.2 y Reales Ejecutorias, C. 801.33 7 Juan de Acha es mencionado por última vez en una escritura de su hijo Pedro Martínez de Acha otorgada el 10 de diciembre de 1558, AHPLR, Juan de Castro, 1558-1560, prot. 484, f. 178r; MOYA VALGAÑÓN, José Gabriel, Arquitectura religiosa..., T. II, p. 40, doc. 140 . Se desconoce si en esta fecha se había retirado a su villa natal y si su hijo estaba a cargo del taller.

8 Archivo Diocesano de Zaragoza (ADZ), Apelaciones, C. 349-7.

9 Juan de Acha pagó, en 1552, 3.000 maravedís a la fábrica de Santa María de Palacio porque su madre los había mandado dar para la obra del retablo mayor; ÁLVAREZ CLAVIJO, Ma Teresa, Las artes en la Iglesia Imperial de Santa María de Palacio de Logroño (siglos XII al XVII), Logroño, IER, 1995, p. 156. También adelantó por Hernando de Soria cierta cantidad que debía abonar para la misma obra; RUIZ-NAVARRO PÉREZ, Julián, Arnao de Bruselas. Imaginero renacentista y su obra en el valle medio del Ebro, Logroño, 1981, p. 56. 
después de fallecer Juan de Acha murió también su nieta, Catalina González, por lo que Pedro González de Belorado quedó como heredero del arquitecto ${ }^{10}$.

Es posible que Acha mantuviera algún tipo de parentesco con los Mutio: Juan Martínez de Mutio y Martín Ibáñez de Mutio. El 8 de abril de 1538 Juan de Acha y Juan Ortiz [de Endeiza o de San Asensio] tasaron una capilla que Juan Martínez de Mutio había realizado en la iglesia abacial de Nájera para María de Ariz quien se quejó de la alta valoración motivada, según su abogado, porque uno de los tasadores era pariente de Mutio y el otro evaluaba habitualmente sus obras ${ }^{11}$. Ambos tasadores eran vizcaínos y no se sabe cuál de ellos tenía parentesco con Martínez de Mutio ni de qué grado era. Es cierto, sin embargo, que los Mutio mantuvieron una fuerte relación con Acha, aunque sospechamos que en 1538 Juan de Acha acabó instalado en Logroño desplazado por los Mutio del territorio de Nájera, a menos que se marchara voluntariamente para no competir con ellos o por no poderlo hacer por disponer de menores recursos económicos. Sin embargo, Juan Martínez de Mutio no lo abandonó y en abril de 1539 se ofreció como fiador de Acha en el contrato de la iglesia de Entrena ${ }^{12}$, seguramente la primera gran obra contratada siendo vecino de Logroño, la que le abrió las puertas del mercado artístico de esta ciudad.

Martín Ibáñez de Mutio se había formado, al menos parcialmente, con Juan de Acha pues le sirvió como criado, según declaró el arquitecto de Ispáster en 1552 durante el pleito habido por la obra de la iglesia de Santa Coloma, lugar de la abadía de Nájera. El abad de Santa María la Real había ofrecido, hacia 1537, la obra de esta iglesia a Juan de Acha, pero no la tomó porque Juan Martínez de Mutio le pidió que se la dejara a su hermano Martín Ibáñez de Mutio y aquel consintió por favorecer a quien había sido su criado. Con anterioridad, en 1535 Juan Martínez de Mutio y Juan de Acha habían contratado conjunta-

10 Datos familiares tomados del pleito entre los herederos de Juan de Acha y el concejo de Entrena; ADZ, Apelaciones, C. 349-7.

11 ARCHV, Pl. Civiles, Zarandona y Balboa (OLV), C. 642.5. La capilla fue contratada por María de Ariz, viuda del doctor Alonso Martínez de Nájera, el 5 de marzo de 1536. El 3 de enero de 1538 Juan Ortiz y Juan de Acha la tasaron en 115.300 maravedís.

12 ADZ, Apelaciones, C. 349-7. Documento de fianza suscrito en Entrena el 19 de abril de 1539 . 
mente la realización del coro alto de la abadía najerense ${ }^{13}$ y es probable que ambos colaboraran en algún momento en la iglesia del hospital de la Madre de Dios de Nájera.

También mantuvo relación con Juan Pérez de Solarte, casado con María Ibáñez de Mutio. Solarte que está documentado como criado de Juan Martínez de Mutio, pudo formarse, como Martín Ibáñez de Mutio, con Juan de Acha en Tricio o, al menos, aprendió de su obra pues repitió el diseño de sus bóvedas de diecisiete claves y treinta y dos combados, por lo demás tomadas de la obra de Martín Ruiz de Álbiz y San Juan de Arteaga en la Redonda de Logroño. Solarte se acordó de Juan de Acha para que, en 1551, tasara la iglesia de San Andrés de Anguiano, la primera obra que había contratado como artífice independiente ${ }^{14}$.

En Logroño, Juan de Acha trabajó para los principales clientes eclesiásticos: los cabildos de la colegial de la Redonda y de las parroquias de Santa María de Palacio y de Santiago. De reconocido prestigio, fue llamado como tasador y veedor a diversos lugares del obispado de Calahorra-La Calzada. En 1542 fue elegido como tercer tasador por el corregidor de Logroño para valorar la obra de la Redonda que, además, llevaba a cabo entonces ${ }^{15}$. El 27 de enero de 1547 la iglesia de San Román de San Millán (Álava) le confió la tasación del templo mientras que los canteros nombraron a Pedro de Lizarazu $^{16}$. En 1548 y enero de 1549 visitó la obra hecha por Pedro de Cubillas en la iglesia de Santiago de Calahorra y declaró que iba errada por seguir "mala traza"17.

13 MOYA VALGAÑÓN, José Gabriel, Arquitectura religiosa..., T. II, pp. 97-99.

14 BARRÓN GARCÍA, Aurelio Á., “La obra del arquitecto tardogótico..., pp. 69-88. Martín de Acha también fue llamado como testigo por Solarte para que declarase sobre la calidad de los materiales invertidos en la construcción de Anguiano.

15 BARRÓN GARCÍA, Aurelio Á., “Martín Ruiz de Álbiz..., pp. 281-282.

16 PORTILLA VITORIA, Micaela J., Catálogo monumental diócesis de Vitoria. T. V. La Llanada alavesa oriental, Vitoria, Obra Cultural de la Caja de Ahorros Municipal de Vitoria, 1982, p. 688. La capilla mayor y nave la habían constuido Pedro de Leceta, vecino de Oramáiztegui, y Pedro de Olazagutia, vecino de Olazagutia. Lizararu tenía vecindad en Villarreal de Urrechua. En caso de discordia entre los tasadores estaba prevista la intervención de Juan de Goyaz, vecino de Bañares.

17 LECUONA, Manuel de, "La parroquia de Santiago de Calahorra. Breves notas históricas", Berceo, 24 (1952), p. 482; CALATAYUD FERNÁNDEZ, Elena, Arquitec- 


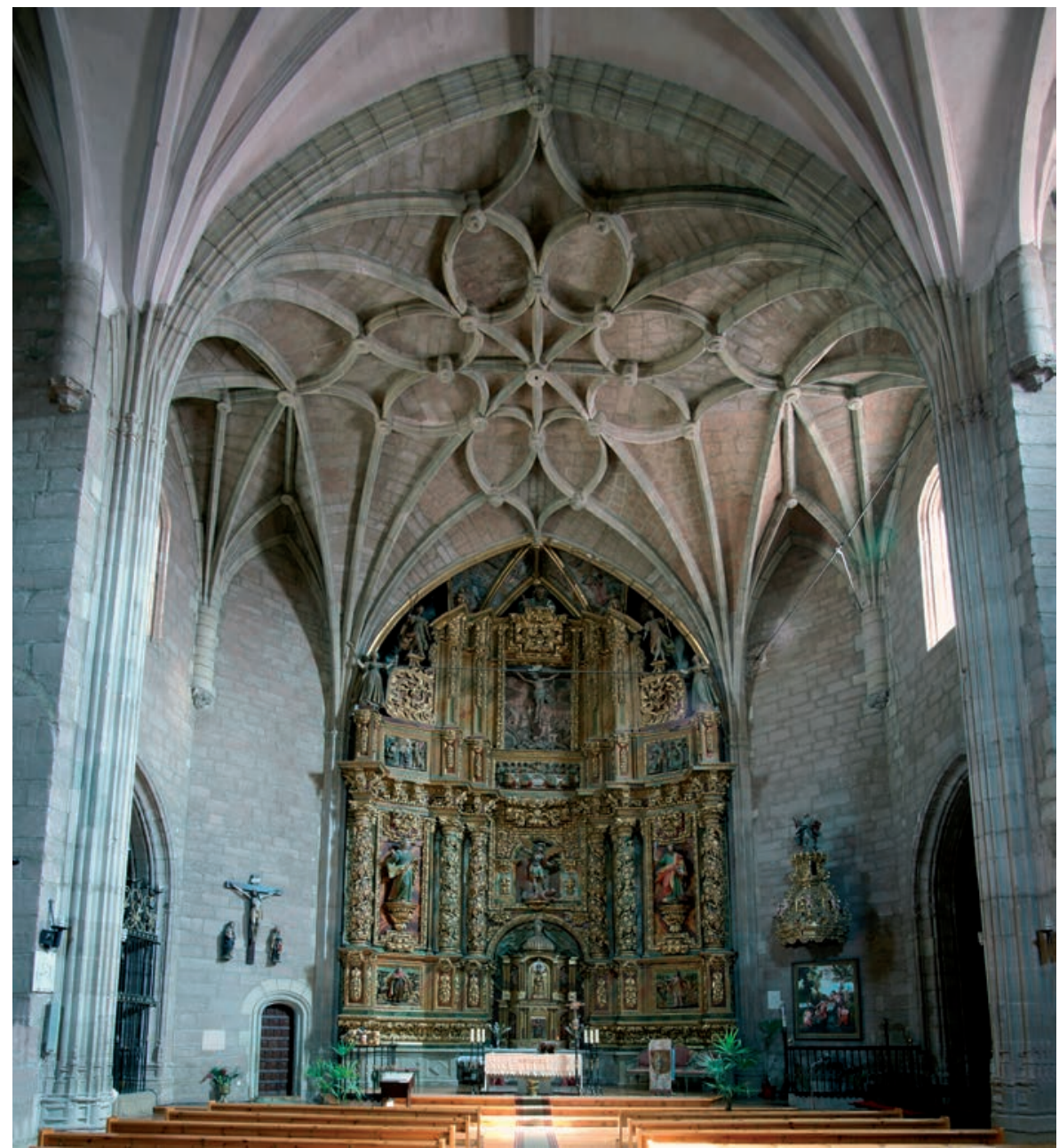

Fig. 2. Capilla mayor. Juan de Acha. 1528-1540. Iglesia de San Miguel. Tricio (La Rioja)

tura religiosa en La Rioja Baja: Calahorra y su entorno (1500-1650), Logroño, Colegio Oficial de Aparejadores y Arquitectos técnicos de La Rioja, 1991, T. I, pp. 358 y 480 (nota 802). MATEOS GIL, Ana Jesús, La iglesia de Santiago el Real de Calahorra. 15001800, Logroño, IER, 1991, p. 22. Pedro de Cubillas se había encargado de la iglesia hasta su fallecimiento en 1544 y después de la visura de Acha se aprobó un nuevo plan propuesto por Pedro de Olabe. Desconocemos si se corresponde con Pero de Cubillas, activo entre 1496 y 1525, que trabajó en el castillo de Enciso y, posiblemente, en la iglesia de Santa María de esta localidad; ROMERO MEDINA, Raúl, "Un cantero tardogótico de posible ascendencia cántabra en Castilla: maestre Pero de Cubillas (1496-1525)", Laboratorio de Arte. Revista del Departamento de Historia del Arte, 19 (2006), pp. 49-66. 


\section{La capilla mayor de la iglesia de San Miguel en Tricio}

Después de las realizaciones de Martín Ruiz de Álbiz, San Juan de Arteaga y Juan de Rasines, Juan de Acha fue el primer arquitecto documentado en La Rioja que recurrió al cierre de capillas con terceletes curvos y combados en tramos de diecisiete claves y treinta y dos combados, como se puede ver en la magnífica capilla mayor de la iglesia parroquial de Tricio, entonces un barrio de Nájera (Fig. 2).

Juan de Acha hubo de tomar el modelo de la obra logroñesa y, aparte de que pudo conocer personalmente la colegial, el arquitecto intermediario en la transmisión del modelo fue Martín de Vergara. Juntos contrataron en 1528 la capilla mayor de Tricio, pero como la levantó personalmente Juan de Acha se puede considerar también que la intervención de Vergara en el contrato fue una especie de presentación y apadrinamiento de un cantero, hasta entonces desconocido, que iniciaba su andadura personal con esta obra. Fue relativamente frecuente que los maestros avalaran a sus discípulos en sus primeras edificaciones.

Martín de Vergara (c. 1477), fue un cantero relacionado con San Juan de Arteaga y Ruiz de Álbiz que pudo trabajar - y sin duda conocer- en la construcción de la Redonda. En febrero de 1520, Martín de Vergara, junto con San Juan de Arteaga, hicieron la primera rebaja en el remate para tomar la reforma de la iglesia de Santiago de Logroño, seguramente en connivencia con Martín Ruiz de Álbiz. Además, en junio del mismo año, en Zarratón -iglesia de Ruiz de Álbiz en la que pudo colaborar - testificó a favor de Ruiz de Álbiz en el pleito que éste mantuvo con la parroquia de Santiago. En junio de 1523 Vergara tasó el despojo del viejo templo de la Redonda que Álbiz - quien lo había nombrado tasador - y Arteaga habían de renovar a continuación ${ }^{18}$. Seguramente Martín de Vergara formó parte de la cuadrilla de canteros empleados en la Redonda y, con anterioridad, había trabajado en otras obras de Álbiz y Arteaga. En 1520, probablemente en compañía de San Juan de Arteaga, había tomado la obra de la iglesia de Fuenmayor en la que había trabajado Juan de Regil quien había levantado cuatro tramos para 1520 pero que, al parecer, estaban para caerse por lo que la iglesia se encomendó en 1520 a Martín de Verga-

18 BARRÓN GARCÍA, Aurelio Á., “Martín Ruiz de Álbiz..., pp. 272, 284 (nota 6) y 286 (nota 50). 


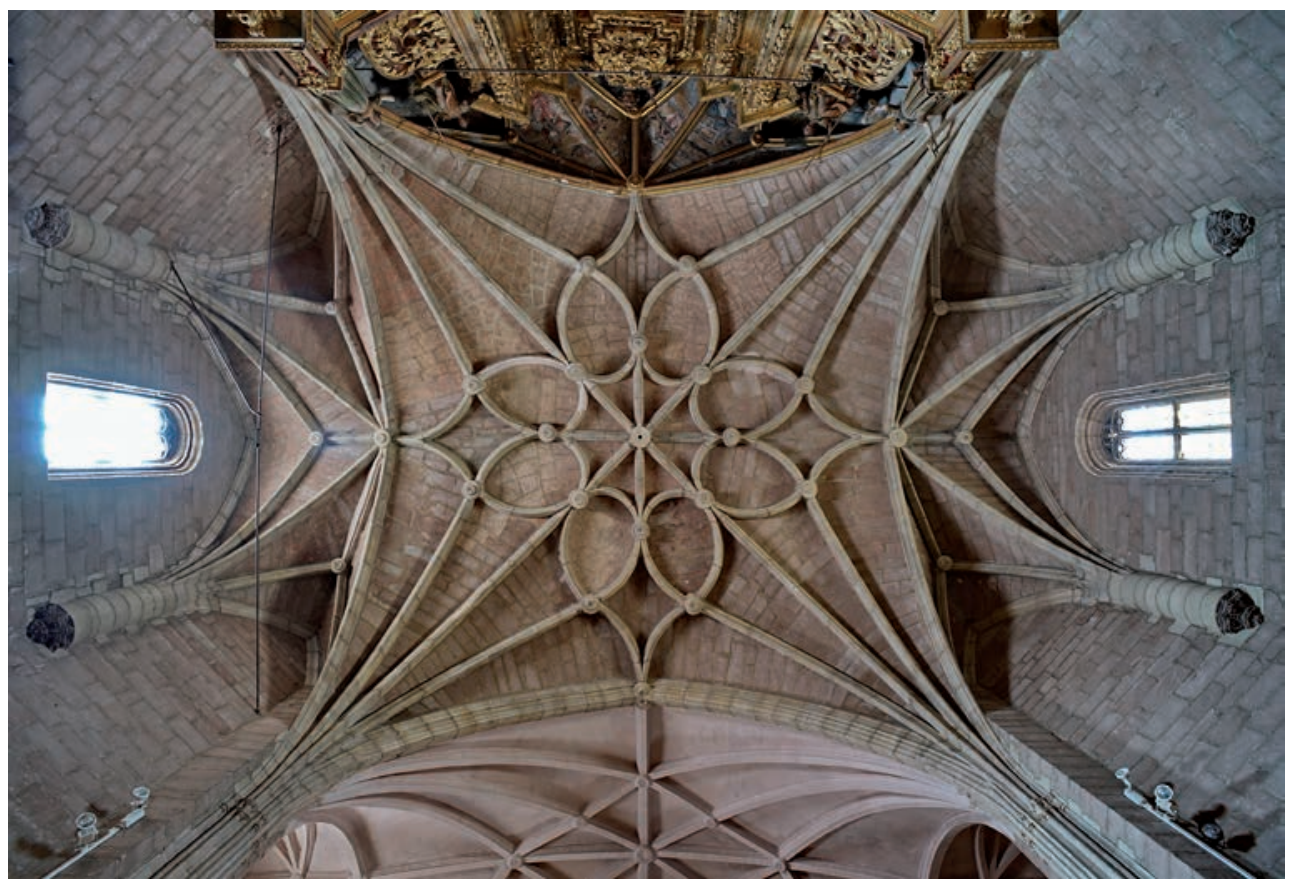

Fig. 3. Bóveda de diecisiete claves y treinta y dos combados. Juan de Acha. 1528-1540. Iglesia de San Miguel. Tricio (La Rioja)

$\mathrm{ra}^{19}$. La nave mayor de la iglesia de Fuenmayor se cubre con bóvedas de cruceros y terceletes rectos que forman una estrella de ocho puntas en torno a la clave polar, dibujo que simplifica la traza de Simón de Colonia en la capilla del Condestable en la catedral de Burgos. Este diseño se había utilizado en el primitivo crucero de la catedral de Calahorra levantado por Juan de Arteaga entre 1503 y $1509^{20}$-ahora encima del coro por haberse prolongado esta catedral con las obras de Juan Pérez de Solarte y su hijo homónimo-. Otro de los tramos centrales de la iglesia de Fuenmayor se abovedó con una cruz que, aunque no presenta terceletes curvos, deriva de la del crucero de la iglesia del convento de Casalarreina. Por último, seguramente este arquitecto se corresponda con el cantero Martín de Vergara que había

19 BARRÓN GARCÍA, Aurelio Á., “Bóvedas con figuras..., pp. 262-263.

20 LECUONA, Manuel de, "La catedral de Calahorra (notas histórico-arqueológicas)”, Berceo, 2 (1947), p. 78; CALATAYUD FERNÁNDEZ, Elena, Arquitectura religiosa en La Rioja Baja..., T. I, pp. 256 y 528. El primitivo crucero, que está alineado con la puerta de San Jerónimo, lo cerró junto con Sancho Pérez de Lequeitio. 
trabajado en la capilla de la Piedad y en el claustro de la iglesia de San Miguel de Oñate antes de $1532^{21}$.

El 22 de junio de 1528, Martín de Vergara y Juan de Acha tomaron la obra de la capilla mayor de la iglesia de San Miguel de Tricio ${ }^{22}$. Una de las cláusulas del condicionado señalaba que debía hacerse de nave única - que es como se refieren al espacio centralizado que estaban contratando- conforme a la traza firmada por ambos canteros y no debía ser ni más ancha ni más estrecha que la iglesia cuyos muros perimetrales estaban construidos parcialmente, bien por Vergara $\mathrm{u}$ otro arquitecto desconocido. Para la longitud de la capilla mayor se remitieron a la "muestra" aunque especificaron que debía contar con las proporciones y medidas adecuadas al arte de geometría. A la forma que debía tener la capilla mayor se dedicaron varios puntos del condicionado porque se deduce que se cambió el plan de la iglesia: se abandonó una cabecera con capillas hornacinas a los lados - como veremos en la iglesia de Entrena; capillas hornacinas que se mantuvieron en el segundo y tercer tramo de la iglesia de Tricio- por una capilla mayor trebolada en la que un grandioso tramo central abovedado con diecisiete claves y treinta y dos combados se expande hacia el muro de cabecera y hacia los lados con tres capillas ochavadas cubiertas cada una por tres tramos de terceletes que la documentación denomina "rincones de los ochabos de la capilla". Todo ello sin que los ochavos laterales excedieran del espacio de las primeras capillas hornacinas que, aunque sin abovedar, estaban construidas ${ }^{23}$, pero que

21 ARRAZOLA ECHEVERRÍA, Ma Asunción, Renacimiento en Guipúzcoa. Tomo I. Arquitectura, San Sebastián, Diputación Foral de Guipúzcoa, 1988, p. 103; BARRIO LOZA, José Ángel y MOYA VALGAÑÓN, José Gabriel, "Los canteros vizcaínos..., p. 265.

22 ARCHV, Pl. Civiles, Fernando Alonso (F), C. 907.2 y Reales Ejecutorias, C. 801.33. Véase el contrato en el apéndice documental. Martín de Vergara era, en 1528, vecino de Navarrete y en la testificación de 1520 señalada dijo ser natural de Vergara. Probablemente fuera responsable, por entonces, de la iglesia de Navarrete, reedificada a partir de 1553 con traza de Juan de Vallejo y Hernando de Mimenza. Las citas que siguen se toman de las referencias señaladas.

23 Hasta el arranque de las bóvedas, también estaban levantadas las capillas hornacinas de los tramos segundo y tercero de la iglesia. Fueron abovedadas, como las capillas correspondientes de la nave mayor por Francisco de Odriozola a finales del siglo XVI y primeros años del siglo XVII; MOYA VALGAÑÓN, José Gabriel, Arquitectura religiosa..., T. I, p. 100. 
había que desmontar para integrarlas con el tramo central y con el ochavo de cabecera a realizar. También los perpiaños debían estar ya construidos y son ligeramente apuntados. Un capítulo del contrato señaló los estribos que debían levantarse en los cantones de las tres capillas ochavadas. Alineados con las esquinas, los contrafuertes son visibles al exterior por su inclinación angular. También se aprecia el empalme del primer tramo del ochavo con la capilla hornacina del segundo tramo que había sido construida con sillares de mayor tamaño.

Además, en el muro del evangelio de la capilla mayor los canteros debían abrir paso a una sacristía que parcialmente se conserva, pues se ha agrandado con posterioridad. Al sur - "a la parte del sol" - y al norte se abrieron dos ventanas como la dibujada en la traza con su mainel, tracería o "claraboya" y moldura ${ }^{24}$; ventana que resulta muy semejante a la que San Juan de Arteaga había abierto en la iglesia de Leiva aunque en el pequeño rosetón superior Acha insertó una cuadrifolia.

Las partes contratantes determinaron que todos los muros, por fuera y por dentro, las esquinas y los relejes estuvieran acabados "a boca de hescoda". Con piedra de la cantera de Buicio en Fuenmayor o de las canteras de San Asensio se habían de hacer los pilares adosados - que la documentación denomina "pies derechos" cuando apoyan en ménsulas -, las molduras, basamentos y capiteles, así como los terceletes de los ochavos o "rincones", las ménsulas - o "replisas labradas de molduras y follajeras sobre que se an de armar los enjarjamentos" - , las jarcias, las crucerías, las claves y las dovelas de los arcos perpiaños. Para las paredes, los estribos y los plementos de las bóvedas - llamados "cascos" - se recurriría a la mejor piedra que se encontrara en las Arenzanas - Arenzana de Arriba y de Abajo- o en Mahave.

Los canteros debían acabar la capilla en el plazo de siete años y la iglesia y concejo del lugar debía transportar a pie de obra todo el ripio, arena, cal y agua que fuera necesaria, aunque la cal habían de elaborarla los arquitectos con la piedra y la madera que les proporcionaran. Además, la iglesia y el concejo se encargarían de abrir los cimientos y de conseguir licencia para extraer piedra de las canteras señaladas

24 Al pie de la ventana del norte, en el lado derecho, se grabó la inscripción "año de $1665^{\prime \prime}$ que - a no ser que se abriera entonces a imitación de la realizada al surha de corresponder con alguna reparación; seguramente al tejadillo levantado para proteger la capilla abierta en el ochavo del lado del evangelio. 
y para transportarla por caminos libres. También les proporcionarían pastos para el ganado y toda la madera necesaria para los andamios y cimbras, y la maroma, sogas y clavazón que se tuviera que utilizar. Por último, se obligaron a proveer casa franca para el aposento de los canteros que, además, tendrían consideración de vecinos para el consumo y almacenamiento de pan y vino. Para abonar la obra les pagarían el primer año 60.000 maravedís entregados en tercios y, hasta acabar la obra y finalizar los pagos después de que se tasase la capilla, les adjudicarían la renta anual de la primicia - veremos que se valoraba en unos 30.000 maravedís - a excepción de 3.000 maravedís que se reservaban cada año para los gastos corrientes de la iglesia.

Al tomar la obra de Tricio, Martín de Vergara contaba con setenta $\mathrm{y}$ un años y, como hemos apuntado, el contrato se puede tomar como una suerte de presentación del maestro a su oficial. Seis días después de la contratación de la capilla, Acha se encargó personalmente de buscar a los fiadores en Lequeitio ya

"que tenia tomada a su cargo e riesgo una obra de canteria e jumetria en el lugar de Triçio que es en la jurediçion de la çibdad de Najera ques e a de dar fecha e derechamente acabada e fabricada una capilla en la yglesia de san Myguel del dicho lugar de Triçio que a de ser capilla mayor conforme al asiento e demuestra e hescretura que tiene zerca dello hecha e otorgada obligacion en forma con el conzejo del dicho lugar de Triçio" ${ }^{25}$.

De manera inusual los fiadores fueron nada menos que ocho personas - entre ellas Juan de Acha el Viejo y Martín de Acha, su hermano ${ }^{26}$ - posiblemente porque la capilla de Tricio fue una de las primeras obras o la obra con la que Juan de Acha se inició como maestro autónomo, y seguramente porque no era conocido como poseedor de suficientes bienes muebles y raíces. El 7 de agosto presentó la fianza en Tricio y aún tuvo que añadir otro avalista: el cantero García Martínez $^{27}$, natural de Ispáster pero habitante en Anguiano

25 ARCHV, Pl. Civiles, Fernando Alonso (F), C. 907.2.

26 Los fiadores fueron: Sancho de Hesameta, Juan de Acha padre del cantero, Juan Ochoa de Hesameta, Sancho de Hesumeta, morador en Carratesga, Martín de Acha, Martín de Landaeta [posiblemente cantero], Juan de Barraynta, Ochoa de Espele, Sancho de Lorízquiz, todos ellos vecinos de Lequeitio, de la anteiglesia de Ispáster y de Guizabinaga; ARCHV, Pl. Civiles, Fernando Alonso (F), C. 907.2.

27 Desconocemos si se trata del arquitecto García que comenzó la iglesia del mo- 
y posiblemente conocido de los lugareños de Tricio. Consta que la construcción la dirigió personalmente Juan de Acha que recibió los pagos y la concluyó en 1540 .

El 10 de diciembre de 1540 Juan Martínez de Mutio, nombrado por el cabildo y concejo y entonces vecino y habitante en San Millán de la Cogolla, tasó la capilla en 798.500 maravedís ${ }^{28}$. De parte del artífice vio la obra Juan de Asteasu, cantero vecino de Laguardia, que la valoró en una cantidad que superaba los 800.000 maravedís. Pedro de Landeta, que había trabajado para Acha en la capilla durante tres años, declaró en 1553 que Asteasu fue despedido por Acha al poco de llegar a Tricio como tasador y que él mismo lo sustituyó en la valoración, aunque finalmente únicamente se presentó la tasación de Mutio porque varios clérigos y vecinos de Tricio comisionados para la valoración propusieron gratificar al arquitecto con la renta de la primicia de un año, siempre que alcanzara 30.000 maravedís, en consideración a la bondad de la obra ejecutada, a la confianza que tenía con el concejo y para que acudiera a realizar las obras que promovieran la iglesia y el concejo más adelante ${ }^{29}$. De 1528 a 1540 el cantero recibió 442.983 maravedís. En los años siguientes hasta 1551, otros 331.425 maravedís, pero como se negaron a pagarle la gratificación acordada reclamó los 30.000 maravedís ante el alcalde del Adelantamiento de Castilla del partido de Burgos en Baños de Río Tobía que sentenció a favor del cantero el 23 de noviembre de 1553 tras la testificación, entre otros, de Pedro de Landeta, entonces avecindado en Arnedo que declaró tener 50 años y ser pariente de Acha en cuarto grado, y de Juan Martínez de

nasterio de San Millán de Yuso. Tampoco se puede saber si tuvo parentesco con García Martínez de Lequeitio que trabajó en la iglesia de Pedroso de 1498 a 1506 o 1507. Seguramente sea autor de las capillas de la nave en la iglesia de San Pedro de Cuevas en Anguiano.

28 La tasación, en el documento número 2 del apéndice. Testificaron los canteros Pedro de Landeta o Landaeta, criado de Acha, y Martín Sanz de Solagura, vecino de Aulestia.

29 En el pleito posterior, los testigos propuestos por Acha declararon que, en realidad, el arquitecto había protestado la tasación de Mutio por sentirse perjudicado en 200.000 maravedís pero que finalmente las partes acordaron pagarle 30.000 maravedís por encima del valor tasado vistas "las boces e pasyon que tenya el dicho maestre Juan de Acha" y "porque el dicho Juan de Acha no yntentase pleyto contra el dicho pueblo e conçejo e fabrica" en palabras de Martínez de Mutio; ARCHV, Pl. Civiles, Fernando Alonso (F), C. 907.2. 
Mutio que dijo tener "50 años pasados". El concejo de Tricio acudió a la Chancillería de Valladolid que volvió a ratificar la sentencia del alcalde del Adelantamiento en febrero y marzo de 1554.

Aunque no se señala en el contrato, en los tramos centrales de los ochavos laterales se han abierto sendas capillas hornacinas de pequeño tamaño que sobresalen del perímetro mural de la iglesia y están pensadas para cobijar enterramientos particulares privilegiados con los que la iglesia podría engrosar sus rentas y sufragar la construcción del templo. La capilla del lado de la epístola ha perdido la crucería original. La del evangelio se cierra con bóveda estrellada de terceletes rectos y ligaduras que forman un rombo en torno a la clave polar.

La plementería de la formidable cabecera de Tricio está cubierta de forma un tanto irregular. El ochavo de cabecera tiene la misma profundidad que las capillas laterales del crucero cerradas con muros enviajados - en realidad uno de los lados continúa el plano inclinado del ochavo de cabecera - de modo que el arquitecto demuestra conocer la cabecera trebolada del monasterio de la Piedad de Casalarreina, aunque en Tricio los extremos del trébol son de escasa profundidad y se cubren con trirradiales dispuestos entre nervios cruceros - es decir, con tres tramos de terceletes en cada ochavo-, a diferencia del convento de dominicas donde se cierran los extremos trebolados sin cruceros diagonales. Las bóvedas de los ochavos, que participan en la sujeción de la capilla, disponen el aparejo a la francesa con extremo cuidado y con despiece de arista simple. Sin embargo, el despiece de la capilla central es descuidado. Se alterna piedra franca en buena parte de los plementos con otra de talla irregular. Aparentemente se dispone en arista doble, de modo que a partir de la parte superior del enjarjamento - que alcanza las claves del primer anillo de los terceletes rectos - la bóveda debería despiezarse en hiladas concéntricas poligonales o circulares desde las primeras torteras de los terceletes hasta la clave polar. Pero encontramos que en los paños romboidales - que incluyen las líneas de clave de la bóveda - continúa el despiece de arista simple, y en los óvalos de los combados e, incluso, en los tramos de la rueda central, el despiece, de apariencia cupuliforme, toma direcciones diversas y aparentemente contradictorias, con un resultado alejado de los abovedamientos de la Redonda o de los ejecutados por Rasines. Como se ha señalado, el espacio central de la 


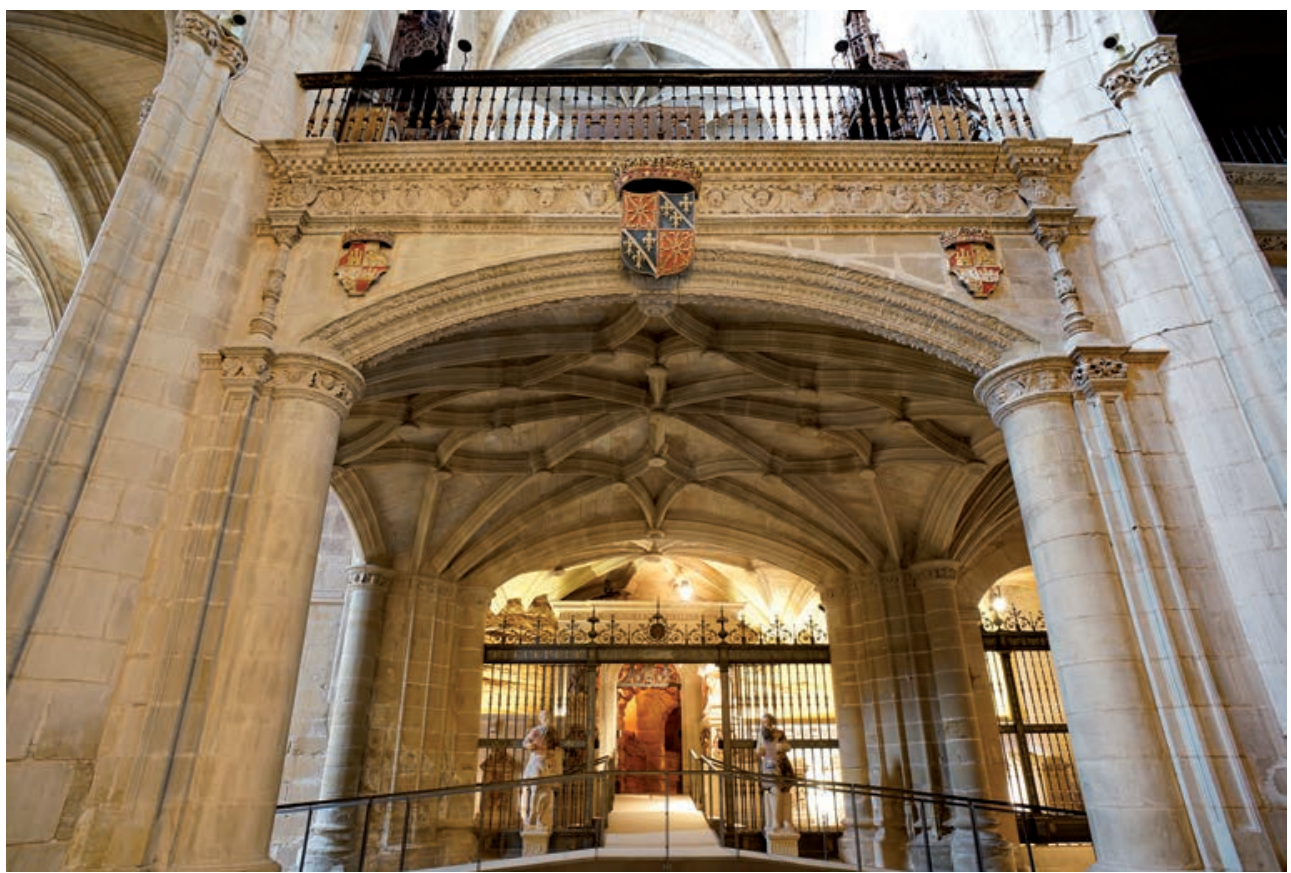

Fig. 4. Coro, sotacoro y panteón. Juan Martínez de Mutio y Juan de Acha. 1535 y ss. Abadía de Santa María la Real. Nájera (La Rioja)

cabecera trebolada de Tricio se cubre con la comentada bóveda de diecisiete claves y treinta y dos combados que había aparecido en la Redonda y que fue, más adelante, tan habitual en la obra de Juan Pérez de Solarte que si no colaboró con Acha en esta capilla la hubo de conocer (Fig. 3).

\section{Juan de Acha en Nájera}

El 12 de enero de 1535 Juan Martínez de Mutio y Juan de Acha concertaron con el abad de Santa María la Real de Nájera la construcción de un coro alto a los pies de la iglesia que ponía fin al coro levantado a fines del siglo anterior en línea con el crucero $^{30}$. Debían ejecutarlo conforme a una traza de los arquitectos y levantarlo en el plazo de un año. El contrato tenía previsto adorno abundante "de arte de romano" en el

30 MOYA VALGAÑÓN, José Gabriel, Arquitectura religiosa..., T. II, pp. 97-99. También, BARRÓN GARCÍA, Aurelio Á., “La galilea y el panteón real de Nájera: Juan Martínez de Mutio, Alonso Gallego y Arnao de Bruselas", BSAA arte, 84 (2018), en prensa. 
antepecho del coro y en los pilares frontales. Para la forma de las guirnaldas, el dibujo de las medallas y el adorno general debían atender lo que pidiera el abad que, como en el reordenamiento del panteón, pudo contar con Alonso Gallego. La figura de las bóvedas del sotacoro estaba indicada en la traza y en el contrato se enriqueció la capilla lateral que había de soportar el pasadizo hacia el coro, pues se había proyectado cerrarla con una sencilla bóveda de cinco claves y finalmente se dispuso que fuera de nueve, seguramente una variante de bóveda estrellada con brazos patados como la que cubría el tramo final de la nave central de la abadía. El tramo central del sotacoro de Nájera se cubre con una bóveda con terceletes curvos de diecisiete claves y veinticuatro combados que Mutio no repetirá en ninguna otra obra suya del territorio de Nájera (Fig. 4). Por contra, la traza del sotacoro se corresponde con la obra que Martín de Vergara y Juan de Acha habían diseñado en 1528 para la capilla mayor de Tricio, de modo que se puede adjudicar cierto protagonismo a Juan de Acha en el diseño del coro najerense. Además, que el abad de Nájera le ofreciera construir, hacia 1537, la iglesia de Santa Coloma indica su ascendencia sobre él y su categoría profesional. Recordamos cómo el templo de Santa Coloma lo cedió a Martín Ibáñez de Mutio su hermano Juan quien rogó a Acha para que lo consintiera.

La bóveda del sotacoro de la abadía de Nájera está construida con aparejo a la francesa y despiece por arista simple en la mayor parte de ella, pero en dos de los paños delimitados por combados curvos el despiece cambia de dirección y las hiladas adoptan disposición cupuliforme de perfil muy plano.

Antes de que, en 1538, se estableciera definitivamente en Logroño Juan de Acha pudo colaborar con su hermano Martín en las iglesias de Sorzano y Baños de Río Tobía. Por la obra que Martín de Acha había realizado en la iglesia de Sorzano le habían entregado la renta de la primicia del lugar correspondiente a los años 1538, 1539 y 1540¹. El 11 de agosto de 1538, Martín de Acha, que se declaró vecino de Baños de Río Tobía, arrendó a Martín de Baños y Juan de Jubera la renta de la primicia de la iglesia de Sorzano del año 1538 por 11.760 maravedís. El

31 AHPLR, Cristóbal Rodríguez, 1538-1539, prot. 474, ff. 366r-367r; citado en GOICOECHEA, Cesáreo, "Artistas y artífices riojanos (Contribución a la Historia de las Bellas Artes en La Rioja)", Berceo, 57 (1960), p. 415; MOYA VALGANÓN, José Gabriel, Arquitectura religiosa..., T. II, pp. 19, doc. 51, y 20, doc. 60. 


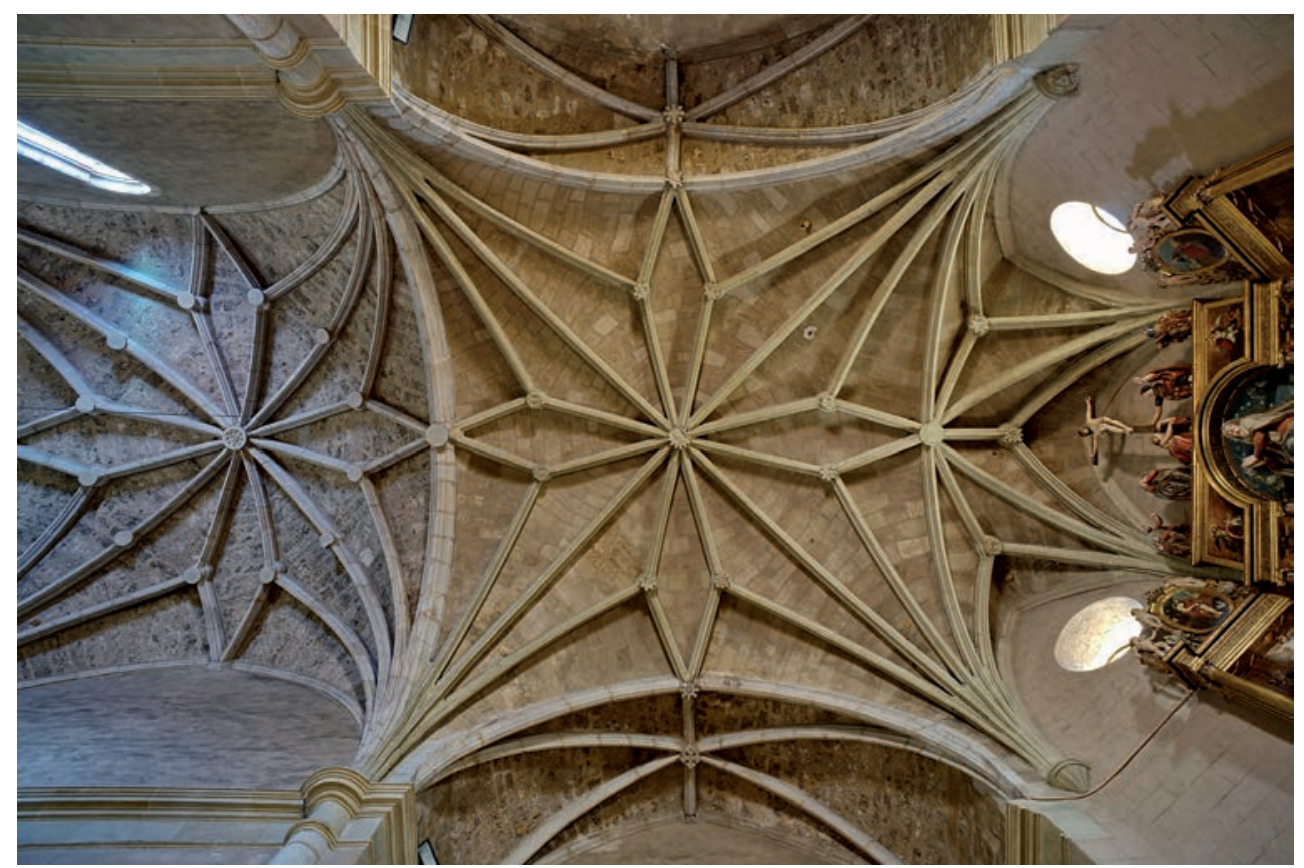

Fig. 5. Bóvedas estrelladas. Martín de Acha. 1530-1538. Iglesia de San Martín.

Sorzano (La Rioja)

14 de enero de 1539, actuando su hermano Pedro de Acha como fiador y siendo vecino de Logroño, traspasó a Juan de Jubera, espadero, las dos últimas anualidades a cambió de que le entregara 10.000 maravedís cada año. La cabecera de la iglesia de San Martín corresponde a una tipología de iglesia de nave única con capillas hornacinas entre contrafuertes que volveremos a ver en la iglesia de Entrena. La cabecera de la iglesia está formada por una capilla mayor contenida por perpiaños de medio punto y cerrada con cruceros diagonales y trirradiales que forman una cruz patada de nueve claves extendida por las líneas de clave de la bóveda. La plementería se cubre con sillería bastante regular que lleva despiece por arista doble de modo que, a partir del enjarjamento, la bóveda se despieza en hiladas circulares cupuliformes (Fig. 5). El arco perpiaño que da al altar mayor comunica con un ochavo cubierto por tres tramos de bóvedas de terceletes, como en Tricio. Sin embargo, las capillas hornacinas laterales, que ascienden a la altura de la capilla central se cubren con una bóveda de cañón construida con piedra toba que está reforzada por cruceros y una ligadura en la línea de clave. El resto de la iglesia está formada por otras dos capillas iguales a la de la cabece- 
ra, pero carecen de hornacinas, como sucederá en la iglesia de El Cortijo. Además, aunque repiten el dibujo de la estrella con cruz patada de la capilla mayor, los plementos están realizados con piedra toba y siguen la disposición cupuliforme que se ha mencionado para la capilla mayor. En los muros perimetrales del exterior se muestra abundante empleo de sillarejo, de modo que la iglesia se levantó con recursos limitados.

La iglesia de San Pelayo en Baños de Río Tobía, donde habían vivido los dos hermanos Acha y donde residía Martín aún en agosto de 1538, también se adjudica a los Acha. A Baños retornó Martín después de instalarse a finales de 1538 en Logroño junto a sus dos hermanos. Como la iglesia de Sorzano, carece de terceletes y combados curvos. El templo de Baños de Río Tobía se transformó en iglesia de tres naves en la segunda mitad del siglo XX. Originalmente era una iglesia de nave única de tres capillas y cabecera cuadrada a la que se han abierto, en fechas próximas a la construcción de la iglesia, dos capillas que forman crucero. Dispone de pórtico de entrada que pudieron comenzar a construir los Acha. En el abovedamiento de la nave y de la cabecera encontramos sencillas bóvedas de cinco claves con aparejo a la francesa y despiezo de arista simple. La capilla de la cabecera tiene ligaduras que recorren las líneas de clave y la capilla central de la nave se adorna con nueve claves y un rombo central al disponer ligaduras entre las claves de los terceletes. Todos los plementos se cierran con piedra franca, salvo la capilla de los pies que lo hace con toba dispuesta en hiladas romboidales en torno al polo.

\section{Juan de Acha en Logroño}

Instalados en Logroño los hermanos Juan, Martín y Pedro de Acha contrataron conjuntamente alguna obra civil: el 25 de agosto de 1538, unas casas para Pedro de Enciso junto al monasterio de la Madre de Dios. Juan cedió pronto esta construcción a sus hermanos - en el nuevo contrato de 30 de junio de 1539- para centrarse en las edificaciones religiosas $^{32}$. Con todo, a Pedro de Acha también se le atribuye haber

32 AHPLR, Cristóbal Rodríguez, 1535-1539, prot. 473, ff. 177v-179r y 513v-514v; 1538-1539, prot. 474, ff. 509v-510v. GOICOECHEA, Cesáreo, "Artistas y artífices..., p. 415; MOYA VALGAÑÓN, José Gabriel, Arquitectura religiosa..., T. II, pp. 19, doc. 52, y 22, doc. 39; ÁLVAREZ CLAVIJO, Ma Teresa, “El convento de Madre de Dios y la casa de los Enciso, en Logroño (La Rioja)”, Berceo, 140 (2001), pp. 197-198. Martín 
intervenido en el abovedamiento de la iglesia o tal vez en el sotacoro de San Bartolomé de Logroño ${ }^{33}$.

Juan de Acha se encargó de las obras de la colegial de la Redonda en 1539 pues en 1542, cuando fue nombrado tasador tercero de esta iglesia en el pleito que sostenía el cabildo de la colegial con los herederos de Martín Ruiz de Álbiz y de San Juan de Arteaga, se dijo que llevaba tres años a cargo de la obra y que había cobrado 600.000 maravedís, cifra muy exagerada que los representantes del cabildo inflaron para negar que tuvieran deudas con los herederos de Álbiz

y Pedro tomaron casas a censo en enero de 1539: Martín, unas casas en el barrio de San Pedro, y Pedro, otras cercanas que se encontraban ubicadas detrás de la iglesia de San Blas; GOICOECHEA, Cesáreo, "Artistas y artífices..., p. 414; MOYA VALGAÑÓN, José Gabriel, Arquitectura religiosa..., T. II, p. 21, doc. 59 y 61. También se sabe que Martín de Acha tomó en mayo de 1539 un aprendiz — Sancho de Amézaga de Santa Maria de Mendaca - , y Pedro de Acha otros tres - Pedro López de Mendizábal, natural de Mendizábal en marzo de 1551; Juan de Gamboa de Arbulena, en junio de 1552; y Juan Miguel de Landa vecino de Nanclares en octubre de 1552; GOICOECHEA, Cesáreo, “Artistas y artífices..., p. 414; MOYA VALGAÑÓN, José Gabriel, Arquitectura religiosa..., T. II, p. 22, doc. 63, p. 29, doc. 93 y 95, y p. 32, doc. 100. Vuelto Martín a Baños de Río Tobía, Pedro de Acha continuó dedicado a obra civil y están documentados los contratos de dos paredes para casas de Pedro de Herrera, Martín de Albelda y Diego de Azcoitia en enero y agosto de 1551; MOYA VALGAÑÓN, José Gabriel, Arquitectura religiosa..., T. II, p. 28, doc. 92, y 29, doc. 96. También se ha publicado el testamento de Pedro de Acha, otorgado el 2 de junio de 1552, AHPLR; Lope de Villoslada, 1540-1550, prot. 478, ff. 320r-322v. MOYA VALGAÑÓN, José Gabriel, Arquitectura religiosa..., T. II, pp. 120-122. Pedro de Acha continuó activo hasta 1568; en marzo de 1555 contrató la fachada y portada de las casas de Diego Romero en Logroño; MOYA VALGAÑÓN, José Gabriel, Arquitectura religiosa..., T. II, pp. 130-131. Ciertamente, Pedro de Acha señaló, en su testamento de 2 de junio de 1552, una deuda parcial que apunta a un pago regular que le adeudaba la iglesia de San Bartolomé: “digo que de la obra que tome a faser de señor san Bartolome desta çibdad se me deben del terzio de navidad pasado asta seys mil maravedis como paresze de una zedula que esta en mi poder firmada de Juan de Pinedo"; AHPLR, Lope de Villoslada, prot. 478, f. 321v; MOYA VALGAÑÓN, José Gabriel, Arquitectura religiosa..., T. II, pp. 120-122.

33 MOYA VALGAÑÓN, José Gabriel (dir), Inventario artístico de Logroño y su provincia. Tomo II (Cenicero-Montalbo de Cameros), Madrid, Centro Nacional de Información Artística, Arqueológica y Etnológica, 1976, p. 323; MOYA VALGAÑÓN, José Gabriel, "Manifestaciones artísticas en Logroño", en Historia de la ciudad de Logroño. Tomo II. Edad Media, Zaragoza, Ibercaja - Ayuntamiento de Logroño - Universidad de La Rioja, 1994, p. 527; LÓPEZ FERNÁNDEZ, Adolfo, La iglesia de San Bartolomé de Logroño. Historia de la conservación del monumento en el siglo XIX, Logroño, IER, 2103, p. 94. 


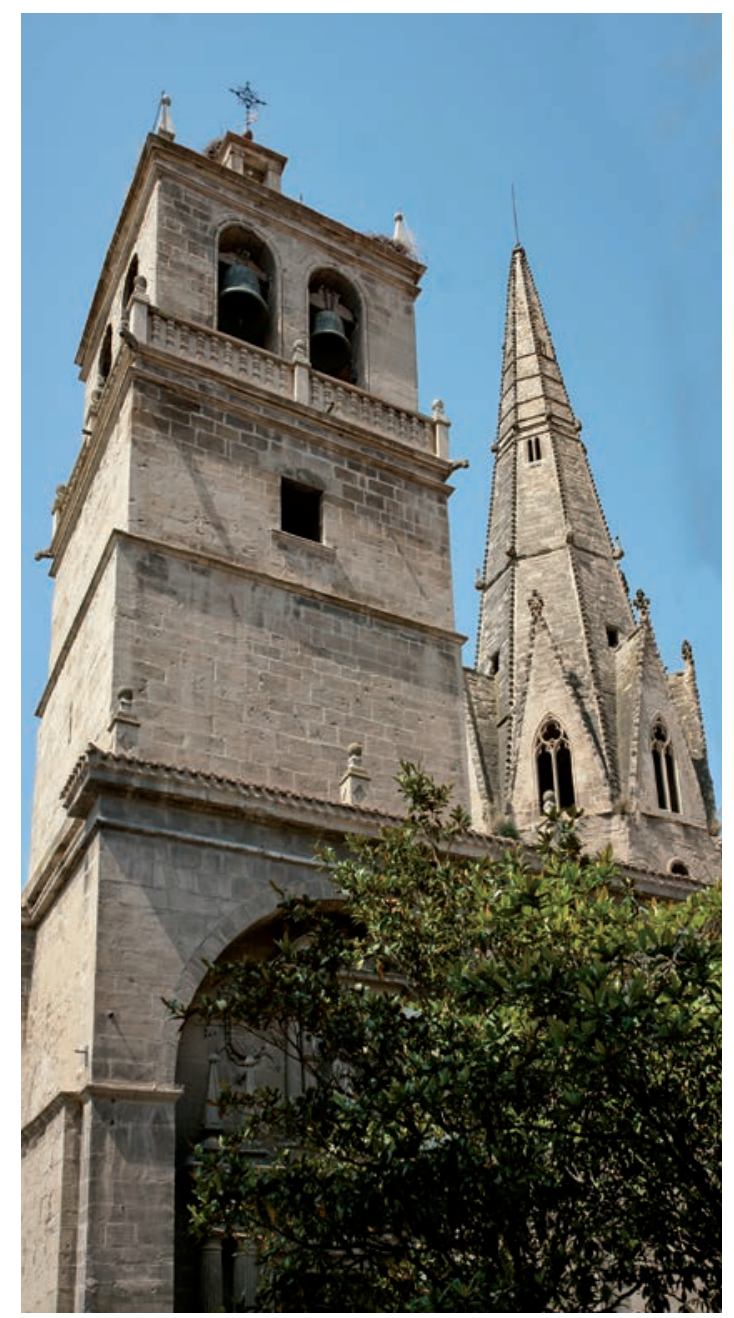

Fig. 6. Torre. Juan de Acha. 1549-1554. Iglesia de Santa María de Palacio. Logroño (La Rioja)

y Arteaga. En las declaraciones testificales se apuntó que Acha era maestro de la obra en ese momento y que concretamente había pincelado la iglesia desde hacía tres años y la había cerrado en referencia a sus trabajos en el muro del hastial ${ }^{34}$. En este muro cerró la puerta central que aún se conservaba de la iglesia antigua ${ }^{35}$, trabajó en las

34 ARCHV, Pl. Civiles, Lapuerta (F), C.446-1; BARRÓN GARCÍA, Aurelio Á. (2015). ÁLVAREZ CLAVIJO, Ma Teresa, Logroño en el siglo XVI: arquitectura y urbanismo, Logroño, IER, 2003, t. II, p 281-282.

35 ÁLVAREZ CLAVIJO, Maㅡ Teresa, Logroño en el siglo XVI..., doc. 111 del apéndice: 
puertas de acceso y colocó una reja en la puerta de entrada desde la calle Herbentia que se encontraba enfrente de la capilla del santo Cristo antes de que se reubicara en la cabecera en la capilla del obispo Pedro González del Castillo. También intervino en la organización de las sepulturas del interior, en el asiento de los órganos y en la torre de la iglesia ${ }^{36}$. Insatisfecho del pago por sus trabajos, pleiteó con la colegial entre 1549 y $1550^{37}$.

De 1549 a 1552 hizo la torre de la iglesia de Santa María de Pala$\mathrm{Cio}^{38}$ que consta de tres cuerpos ligeramente decrecientes. El primero sirve de pórtico de entrada a la iglesia y el último - el cuerpo de campanas - se abre con vanos de medio punto dobles en cada lado. Concluida la torre fue tasada en mayo de 1552 por el entallador Juan de Mordán y el cantero Juan de Landara ${ }^{39}$. Al año siguiente le acabaron de pagar la obra y otorgó carta de finiquito por 366.250 maravedís. Veremos que un diseño semejante se escogió para realizar la torre de la iglesia de Santiago (Fig. 6).

En 1554, junto con Juan Pérez de Obieta y Pedro de Rasines, presentó postura para la reedificación de la capilla mayor del monasterio jerónimo de La Estrella que el conde de Nieva, Diego López de Zúñiga, buscaba reedificar como panteón familiar. El conde pretendía construir una capilla centralizada para la que había aportado un es-

en 1544 se le pagó a Juan de Acha "por el aderezo de los caçones de la puerta de lo viejo de la dicha yglesia que sale hazia los lagos y por cerrar la otra puerta que hera prençipal de lo viejo".

36 ÁLVAREZ CLAVIJO, Mำ Teresa, Logroño en el siglo XVI..., p. 278 y doc. 114 del apéndice documental: en 1544 el mayordomo de la fábrica de la Redonda abonó 2.127 maravedís a Juan de Acha, por los oficiales "que anduvieron en la hobra de los suelos de los cadahalsos y por çiertas piedras suyas que le tomaron". También docs. 119,125 y 126.

37 ÁLVAREZ CLAVIJO, Maㅡ Teresa, Logroño en el siglo XVI..., t. II, p. 283. En 1549 y 1550 la fábrica mantuvo un pleito con el cantero Juan de Acha - docs. 135 y 138 del apéndice - que reclamaba cierto dinero por su intervención en la obra.

38 ÁlVAREZ CLAVIJO, Mํㅡㄹ Teresa, Las artes en la Iglesia Imperial de Santa María de Palacio de Logroño (siglos XII al XVII), Logroño, IER, 1995, pp. 75-79 y 219-220, doc. 15. El finiquito se firmó en diciembre de 1555. También, ÁLVAREZ CLAVIJO, Maㅡ Teresa, Logroño en el siglo XVI..., t. II, pp. 308-310.

39 Pedro de Acha citó en su testamento de 2 de junio de 1552 a Juan de Landara o Langara como criado suyo; AHPLR, Lope de Villoslada, prot. 478, f. 321v; MOYA VALGAÑÓN, José Gabriel, Arquitectura religiosa..., T. II, pp. 120-122. 


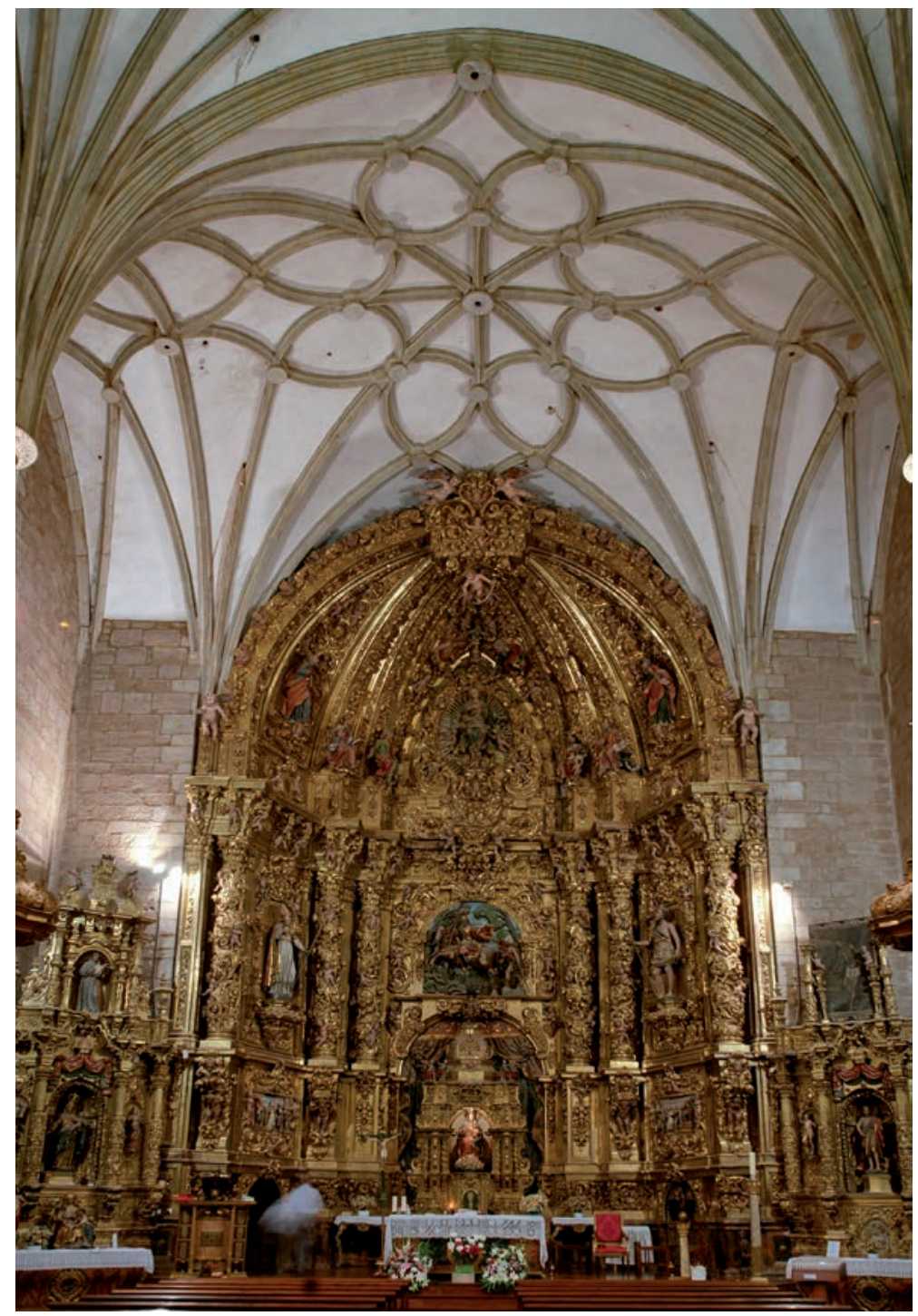

Fig. 7. Capilla mayor. Juan de Acha. 1539-1558. Iglesia de San Martín. Entrena (La Rioja)

quemático rasguño personal, pero descartó todas las posturas ofrecidas porque le parecieron de excesivo valor ${ }^{40}$.

40 Archivo Histórico Nacional, Clero Secular_Regular, Carp. 1062; CADIÑANOS BARDECI, Inocencio, "El Monasterio de La Estrella y Navarrete el Mudo". Boletín Real Academia de Bellas Artes de San Fernando, 63 (1986), p. 267; BARRÓN GARCÍA, Aurelio Á., "Primeras obras en La Rioja..., pp. 45-46. 


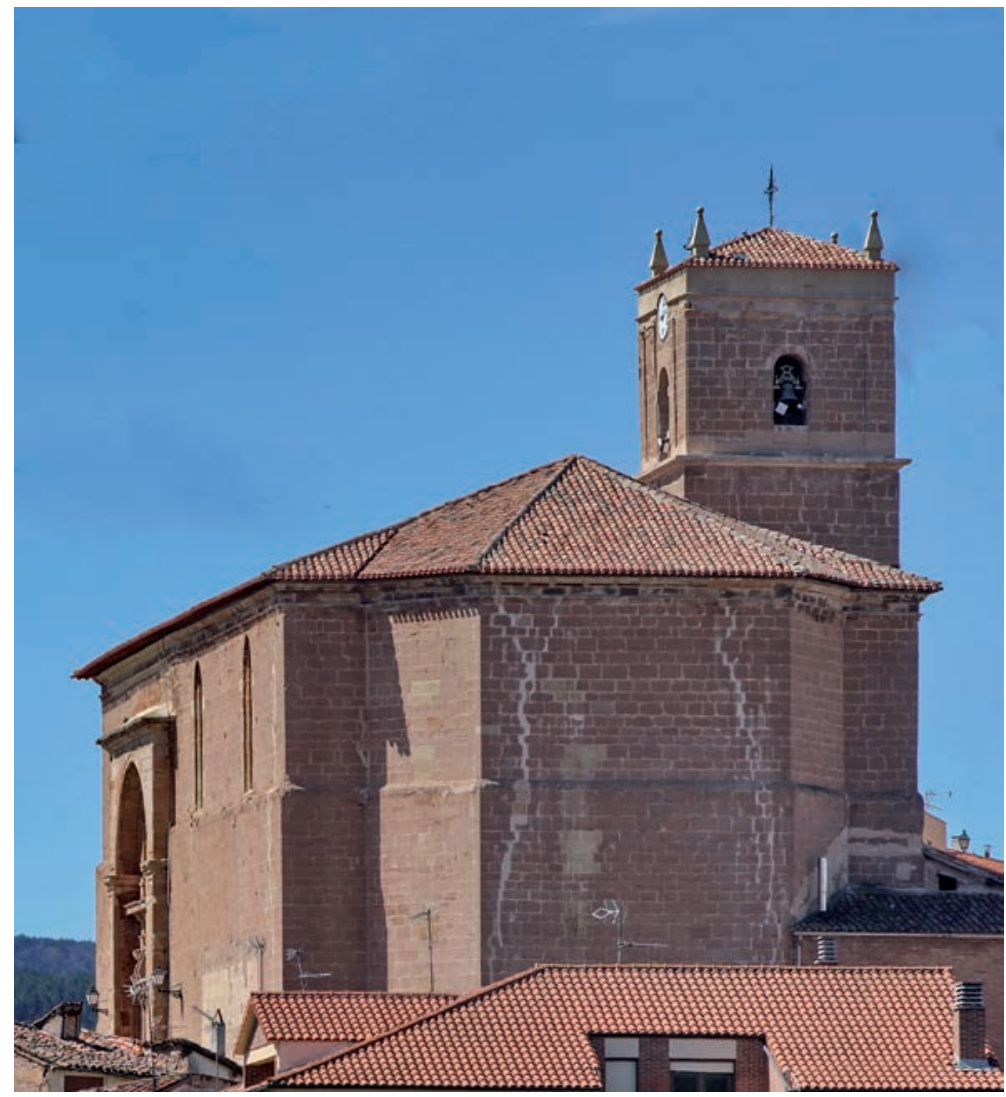

Fig. 8. Vista exterior. Juan de Acha. 1539-1558. Iglesia de San Martín. Entrena (La Rioja)

\section{1. La iglesia de Nuestra Señora de Entrena}

La iglesia de Entrena se proyectó según la tipología de templo comentado al presentar la iglesia de Sorzano, pero con capillas hornacinas a lo largo de todo el edificio (Fig. 7 y 8). El modelo se remonta a principios del siglo XVI y Juan de Regil - también llamado Juan de Logroño y Juan de Mendizábal - edificó algunos de los ejemplos más tempranos y representativos. Es característico de estas iglesias que los muros exteriores se presenten lisos y escondan los contrafuertes, dispuestos hacia el interior para permitir abrir altas capillas.

La iglesia de Nuestra Señora la Antigua de Entrena - ahora, de San Martín - fue el primer contrato importante de la etapa logroñesa de Juan de Acha. Los primeros pasos para acordar la reedificación de la iglesia coincidieron con la llegada de los hermanos Acha a Logro- 
ño en agosto de 1538. El 11 de agosto de 1538 el cabildo de la iglesia parroquial de Entrena y el concejo del lugar, después de haber contrastado diversas opiniones de arquitectos sobre el estado ruinoso de la iglesia y su posible reforma, acordaron nombrar una comisión para conseguir licencia de edificación de nueva obra del obispo de Calahorra-La Calzada y de sus provisores y vicarios generales:

"Por quanto la dicha yglesia parroquial e obra della esta muy peligrosa e quanto mas ba esta mas en peligro porque se abre por muchas partes e an avido consejo con maestros de canterias los quales an dicho que no se puede remediar sino se haze de nuevo e que no fue bien çimentada por çiertas razones que dieron los dichos maestros por ende que visto el gran daño que se puede recresçer en no estar la dicha yglesia fixa que ellos son de un consentimiento e de una voluntad de que se derriba la dicha yglesia e se torne a hedificar de nuevo con la piedra y despojo que della se sacare en la parte e lugar que tres o quatro ofiçiales de çiençia e de conçiençia dixeren e aclararen que se haga" ${ }^{\prime 1}$.

Por fin, el 20 de febrero de 1539, contrataron la realización de un nuevo templo con Juan de Acha, maestro elegido después de buscar cantero de ciencia y conciencia y "persona caudalosa", pues la escasez de bienes era un obstáculo fundamental para que pudieran ejercer el oficio nuevos arquitectos. Señalaron que no "an podido hallar ninguna [persona] que la haga con mejores condiçiones" $y$, como veremos, Acha ofreció condiciones poco comunes, necesitado como estaba de tomar una primera obra en Logroño. En lo básico Acha debía hacer la iglesia según una traza propia y complementarla con una torre - de la altura de la iglesia - y un caracol de subida a las campanas. El templo tendría las gradas, altares, ventanas y puertas necesarias y debía entregar la obra pincelada por dentro. Las dovelas o "vueltas" de los arcos, de las puertas, de las ventanas y las paredes de las esquinas o estribos y las paredes interiores serían de piedra de Lamadriz ${ }^{42}$. Los plementos de las bóvedas - denominados "capa" - serían de toba. La sacristía había de disponerse debajo del altar mayor, donde ahora se encuentra un espacio. Se esperaba su conclusión en diez años - La

41 ADZ, Apelaciones, C. 349-7. La transcripción del contrato y la tasación, en el apéndice documental.

42 No hemos localizado esta cantera. En Entrena existe un término denominado la Cantera y en la vecina Lardero otro que es llamado Madrid. El barrio de Debajo de Berceo fue conocido en la Edad Media como Madriz. 
iglesia podía nombrar a dos veedores supervisores y, además, se añadió una clausula económica excepcional: el cantero debía invertir en el edificio el doble de dinero del que pusiera la iglesia. Estaba previsto que cada año el cabildo y concejo entregaran 30.000 maravedís y, de acuerdo con lo capitulado, Acha debía aportar de sus bienes 60.000 maravedís. Como era habitual, estaba prevista la participación de los parroquianos y que el concejo facilitara el proceso constructivo ofreciendo al arquitecto canteras, caminos carretiles francos, sitio para las caleras, madera de los montes de la villa para el andamio y la tablazón necesarias, excepto que no podría tomarla del término de la Dehesa de la villa. También pastos libres para el ganado y almacenar pan y vino libremente para él y su cuadrilla. Una vez acabada la obra sería tasada por dos personas nombradas por las partes. El contrato se consumó con la presentación de fianzas el 19 de abril de 1539. Fueron sus fiadores el cantero Juan Martínez de Mutio, entonces avecindado en San Millán de la Cogolla, y Pedro González, escudero y vecino de Arenzana de Arriba. Hemos apuntado que Mutio pudo dificultar la carrera de Juan de Acha en la zona de Nájera porque favoreció a su hermano Martín Ibáñez de Mutio, pero este fundamental y complejo contrato demuestra la proximidad de uno y otro.

La construcción comenzó pronto y avanzó la edificación del edificio. Consta que en junio de 1547 la iglesia adquirió un solar "debajo de la plaza" y unas casas "para hacer la iglesia nueva"43. En 1550 residía en la localidad Juan Martínez, cantero de Ispáster y criado de Juan de Acha ${ }^{44}$.

Fallecido Acha, sus herederos -Pedro González de Belorado y Pedro Martínez de Acha - quisieron que se tasase el valor de lo edificado y así lo solicitaron el 8 de enero de 1561. El cabildo y concejo de Entrena no lo consintió porque razonaba que antes de tasarse la obra debía estar completamente acabado el edificio. Además, consiguieron que 14 de diciembre de 1561 Pedro Martínez de Acha - avecindado en Navarrete en este momento- se apartase de la demanda para ofrecerse a concluir la iglesia como cantero e hijo del contratista. En la probanza que solicitaron los provisores en enero de 1562, Pedro González

43 MOYA VALGAÑÓN, José Gabriel, Arquitectura religiosa..., T. II, p. 25, docs. 79 y 80 .

44 ARCHV, Pl. Civiles, Fernando Alonso (F), C. 1125,3. 
de Belorado demostró que era legítimo heredero de Juan de Acha a través de su esposa - Magdalena González, hija del cantero- y de su hija Catalina González, aunque ambas habían fallecido: la esposa con anterioridad a Juan de Acha y la nieta con posterioridad. Uno de los testigos presentados fue Pedro de Landeta o Landaeta, cantero de 60 años que había sido criado de Juan de Acha. El interrogatorio propuesto por el cabildo y concejo de Entrena nos informa que Juan de Acha había fallecido en su tierra originaria, en el Señorío de Vizcaya.

Los vecinos alegaron que habían entregado al cantero 3.000 ducados en dinero aparte de lo que habían gastado en la piedra para la cal, la "toba para la capa de lo que esta hecho", la apertura de los cimientos, el yeso, el ladrillo y la madera entregada. Todos señalaron que estaban edificadas dos capillas principales con cuatro capillas hornacinas y que faltaban otras dos capillas y sus hornacinas laterales, el coro, la torre y dos puertas ${ }^{45}$. Los provisores fallaron a favor del heredero, pero el cabildo y el concejo apelaron, en febrero de 1563, al arzobispado de Zaragoza.

La capilla mayor, de proporciones cuadradas se cubre con el diseño ya comentado de diecisiete claves y treinta y dos combados. El altar mayor se cobija bajo un ochavo y dos capillas hornacinas dilatan el espacio de la cabecera por los lados. Todo se cubre con nervaduras de piedra franca mientras que los plementos, de piedra toba, están completamente encalados. El primer tramo de la nave, también concluido bajo la dirección de Juan de Acha, es de planta rectangular y se cierra con 15 claves, terceletes rectos y contraterceletes curvos y un dibujo de combados tendidos desde las claves de los terceletes rectos. Lleva también ligaduras por las líneas de clave que están curvadas para equilibrar mejor los nervios de la bóveda, que en esta obra acaban en ménsulas de factura renacentista colgadas a considerable altura.

Los estribos del edificio se ocultan en las hornacinas y todo el perímetro de la iglesia carece de contrafuertes a la vista, incluso en el ochavo de la cabecera. En los dos tramos finales del templo, en la puerta

45 Juan de Montoya, vecino de Entrena y mayordomo de la iglesia declaró que "la piedra toba que se truxo para cobrir las dichas capillas las truxo el conçejo de la dicha villa por sus veredas del termino de la villa de Nalda a la dicha villa de Entrena y se la ponian en la hobra de la dicha yglesia a costa del dicho conçejo". Además, se había labrado la toba a costa del concejo mediante contrato con "fulano Oribe", vecino de Nalda. Según su declaración, Acha había recibido 884.598 maravedís, más otros 51.886; ADZ, Apelaciones, C. 349-7. 


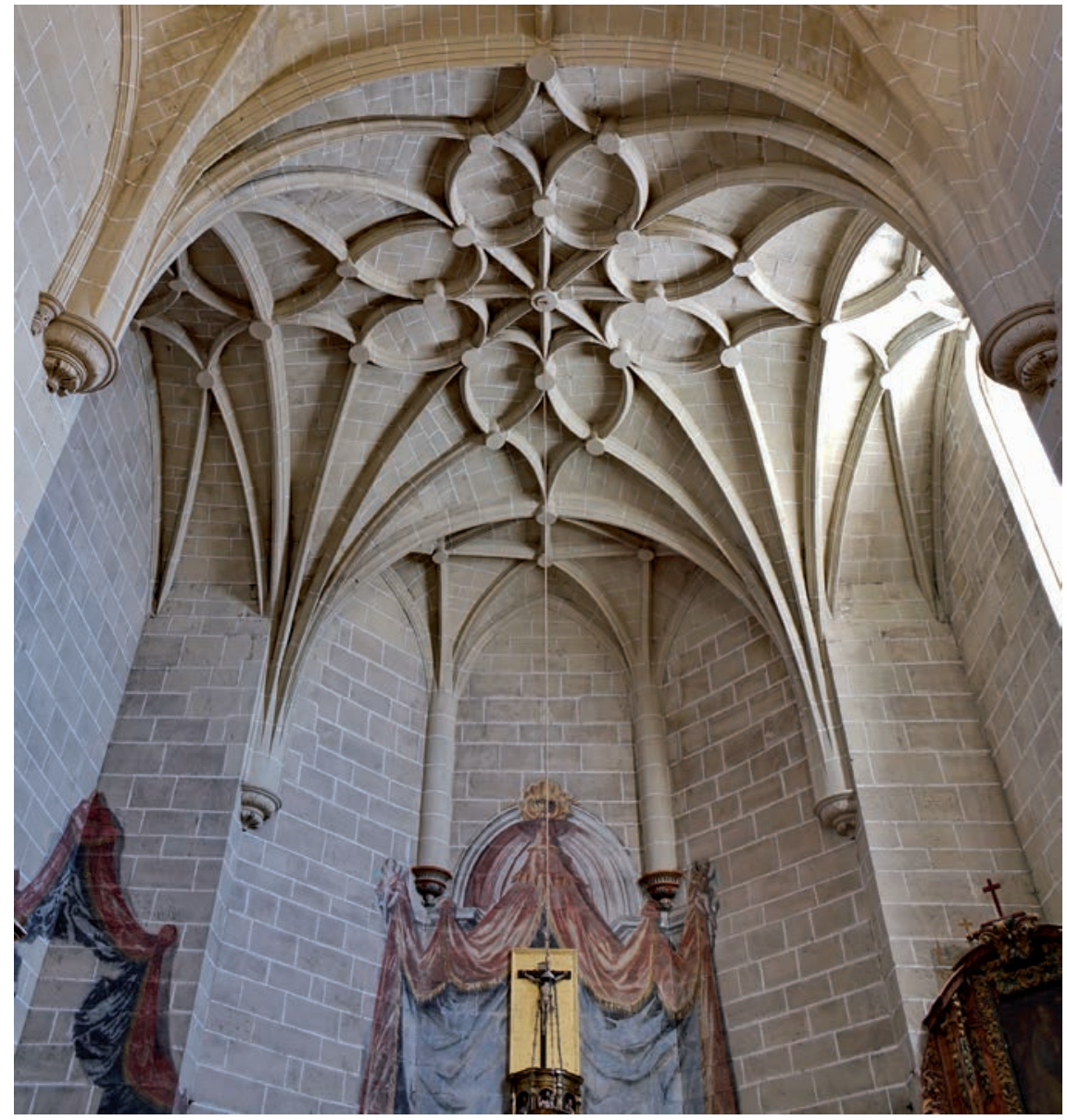

Fig. 9. Capilla mayor. Juan de Acha. 1544-1555. Iglesia de Santa Marina. El Cortijo (La Rioja)

de acceso situada al norte y en la torre se ha seguido básicamente el limpio y espacioso plan del arquitecto trazador.

4. 2. La iglesia de Santa Marina de El Cortijo y la torre de la iglesia de Santiago

Las obras de la iglesia de El Cortijo comenzaron en 1544 con pagos anuales de 13.800 maravedís ${ }^{46}$. En diciembre de 1555 estaba remata-

46 MOYA VALGAÑÓN, José Gabriel, Arquitectura religiosa..., T. II, p. 91; BARRIO LOZA, José Ángel y MOYA VALGAÑÓN, José Gabriel, “Los canteros vizcaínos..., p. 176. 


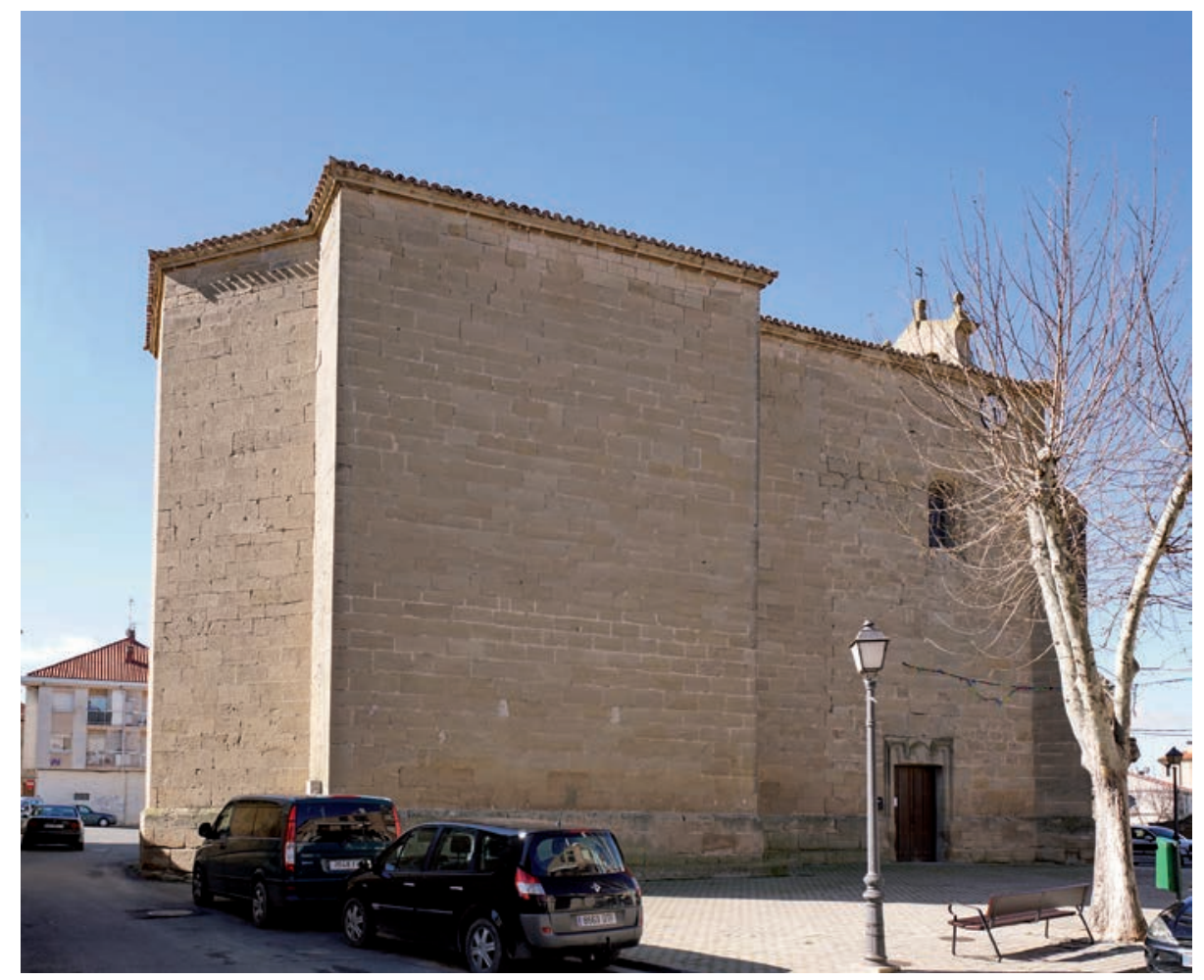

Fig. 10. Exterior. Juan de Acha. 1544-1555. Iglesia de Santa Marina. El Cortijo (La Rioja)

da la cabecera de la iglesia y se procedió a tasar lo ejecutado ${ }^{47}$ : la capilla mayor, el ochavo del altar mayor, dos capillas hornacinas, tres altares con sus gradas y losado, una pila de bautizar y las paredes del perímetro de la iglesia. Por elección del comitente intervino como tasador Jorge de Olate, cantero vecino de Lapoblación, mientras que Bartolomé de Arta, cantero de Logroño, fue nombrado por el arquitecto. Valoraron lo realizado en 729.500 maravedís, pero al día siguiente expusieron que se habían equivocado al sumar con guarismos y que, en realidad, la tasación correcta alcanzaba 500.500 maravedís. Dado el valor establecido, posiblemente el concejo había proporcionado toda la piedra del edificio. Testificó en la tasación Pedro Martínez de Acha que sin duda colaboraba con su padre.

47 La tasación se hizo los días 18 y 19 de diciembre de 1555; AHPLR; Pedro de Medina, 1555-1556, prot. 489, ff. 140r-143v; MOYA VALGAÑÓN, José Gabriel, Arquitectura religiosa..., T. II, p. 35, docs. 116-117. 
La iglesia de Santa Marina de El Cortijo participa de la limpieza mural comentada en la obra de Entrena (Fig. 9 y 10). También aquí están todos los contrafuertes ocultos al exterior y embutidos entre las capillas hornacinas. Lo construido por Acha en la cabecera repite, uno por uno, los elementos utilizados en la iglesia de Entrena, pero en El Cortijo se utilizó piedra franca de excelente calidad en los muros y en el despiezo de la plementería que en la capilla mayor es por arista doble con hiladas poligonales concéntricas en tono al polo a partir de las claves de los terceletes.

El Cortijo, barrio de Logroño ${ }^{48}$, era dependiente de la iglesia de Santiago y Juan de Acha pretendió levantar la torre y portada de esta iglesia. Los diputados, mayordomos y parroquianos de la iglesia de Santiago habían publicado edictos en los cantones públicos de Logroño llamando a los canteros que estuvieran interesados en realizar la torre y portada y para que trajesen sus trazas y posturas el domingo 6 de septiembre de 1551. Llegado el día se presentaron Juan de Acha, Juan de Landerrain - que no sabía escribir - , Martín de Landerrain y Bartolomé de Arta. Vistas las trazas ofrecidas, los comitentes escogieron la de Acha y le pidieron que presentara su condicionado ${ }^{49}$. La torre la había proyectado cuadrada con treinta y cuatro pies de lado y ciento cincuenta pies de alto. Dividida en tres cuerpos: el inferior cobijaría un pórtico con la portada de acceso a la iglesia en arco de medio punto, el cuerpo intermedio contendría un aposento para sacristán y campanero, y el superior abrigaría el cuerpo de campanas. Por encima de la altura señalada habría un remate con chapitel de estructura de madera cubierta con hoja de Milán - u hojalata-. Se comprometió a levantar la torre y hacer la portada en diez años y por 2.500 ducados siempre que le abonaran cada año 150 ducados. Sin embargo, los comitentes acordaron que únicamente se rematara la torre - sin la portada ni el chapitel- y que la puja se hiciera al anochecer, como era costumbre, con el sistema de candela encendida y repitiendo el pregonero público en alta voz las posturas que se ofrecieran.

48 Era un barrio modesto. En el pleito que la iglesia de Santiago mantuvo con Martín Ruiz de Álbiz en 1520 se especificó que en Santiago había 330 parroquianos de los que 30 vivían en El Cortijo, ÁLVAREZ CLAVIJO, Ma Teresa, Logroño en el siglo XVI..., t. II, p. 260 y doc. 19 del apéndice.

49 ARCHV, Pl. Civiles, Varela (OLV), C. 941.8. En el apéndice documental se transcribe el relato del remate hecho por el escribano del acto.. 
Comenzó Juan de Acha proponiendo 2.000 ducados. Siguieron otras ofertas de distintos licitadores: Juan de Landerrain, Bartolomé de Arta, Juan de Landerrain, Juan de Acha, Juan de Landerrain, Pedro de Medecilla y finalmente Martín de Albiztur y Juan de Acha prácticamente al mismo tiempo, pero señalando el escribano que él oyó a Albiztur cuando la vela se apagó.

Contra lo que se había publicado, acabado el acto, Juan y Martín de Landerrain ofrecieron 1.400 ducados para la hechura de la torre. Al día siguiente Pedro de Medecilla ofreció 1.390 ducados, pero el mayordomo y diputados firmaron el contrato con Juan y Martín de Landerrain ${ }^{50}$.

El día 16 de septiembre de 1551 Juan de Acha reclamó por haber sido el último ponedor en el remate a candela y molesto e intrigado con los comitentes porque atendieron una postura de Martín de Albiztur que ni él ni otros habían escuchado. Además, el licitador no era cantero sino escribano ${ }^{51}$ y se había coordinado con los Landerrain para cederles la obra.

El 13 de enero de 1552 el teniente de corregidor de Logroño abrió proceso de probanza mediante testificaciones. El interrogatorio propuesto por Acha describe el sistema de contratación mediante candela ${ }^{52}$. El arquitecto dirigió las preguntas para sostener que en el re-

50 Martín de Landerrain, fallecido en 1564, era padre de Juan; PASTOR ABÁIGAR, Víctor, "Juan de Landerrain. Un maestro cantero guipuzcoano en Navarra”, Príncipe de Viana, 201 (1994), pp. 89-115.

51 ARCHV, Pl. Civiles, Varela (OLV), C. 941.8. Acha sostuvo que:

"por ser obra en que se elige la yndustria de la persona y en este caso no pueden zederselos semejantes derechos ni cunplirlos unos por otros demas que se puso a la almoneda para que hiziesen postura y se rematasen en maestros canteros y pues no lo es el dicho Martin de Alviztur no pudo hazer postura ni hezeder derecho".

52 ARCHV, Pl. Civiles, Varela (OLV), C. 941.8. Se describe en la quinta y novena preguntas del interrogatorio: $\mathrm{V}$ :

"Yten si saben que de veynte treynta quarenta años a esta parte a seydo y es costunbre husada y guardada en esta çiudad en la dicha yglesia y en las otras que cada y quando se a de rematar alguna obra de las yglesia se remata a la candela desta manera que ponen una candela enzendida para que los maestros que acostunbran hazer semejantes obras agan posturas entretanto que arde la candela y que la hultima postura questa hecha al tienpo que se muere la candela es avida por remate y en ella se remata la obra y la obra a de quedar con quien hizo la dicha postura y no se puede dar a otra persona alguna". 
mate no podían licitar quienes no fueran canteros y para establecer que él ofreció la última postura antes de que se muriese la candela. Muy interesante fue la declaración del pregonero público, Pedro de Salvatierra, pues confirmó lo sostenido por Acha ${ }^{53}$. Entre los testigos propuestos había algunos carpinteros, yeseros y dos canteros: Bartolomé de Arta (c.1523) y Pedro de Urruzono (c. 1520).

Albiztur y los Landerrain dejaron que pasara el tiempo y comenzaron la edificación de la torre. Finalmente, Juan de Sosa, juez de residencia en Logroño, sentenció a favor de Acha el 10 de abril de 1553. El mayordomo y parroquianos de Santiago apelaron a la Chancillería ese mismo mes y escribieron que Juan de Acha no podía atender las obras que tomaba por estar muy ocupado y

"por ser como es hombre de poco caudal y que no tiene posibilidad para haçer la dicha obra porque tiene otras muchas y ninguna dellas acaba ni puede cumplir con todas ellas y abiendo otros muchos ofiçiales muy buenos y honbres de verdad que podian muy mejor cumplir y acavar la dicha obra".

Los jueces de la Real Chancillería revocaron la sentencia de Juan de Sosa y fallaron a favor de la iglesia de Santiago el 11 de octubre de

IX:

"Yten si saven en verdad que al tienpo que se murio la dicha candela y por ser la postrera vaxa la que hizo el dicho Juan de Hacha se le remato la dicha obra por el pregonero y dixo el pregonero a la una a las dos a la terzera buena prole haga a Juan de Hacha y ansi quedo rematada la obra".

53 ARCHV, Pl. Civiles, Varela (OLV), C. 941:

"A la otava pregunta dixo que lo que sabe es que estando la candela hençendida la postrera vez y andando este testigo pregonandola desde la yglesia asta el canton de la calle de Santiago yendo y viniendo a la yglesia le dixeron que pregonase la vaja quel dicho Juan de Acha avia hecho de los dichos diez ducados e ansi este testigo fue pregonando la dicha vaja e andandola pregonando le llamaron para que hiçiese el remate porque hera cayda la candela e ansi este testigo entro en la dicha yglesia y vio la dicha candela que hera cayda del cuchillo porque se trato que por quitar diferençias se pusiese en un cuchillo y que la postura que estuviese hecha quando la candela cayese del cuchillo fuese avida por remate e ansi se cayo la candela con la postura y vaja del dicho Juan de Acha y le dixeron que rematase e ansi este testigo torno a pregonar a la una a las dos a la terçera buena prole aga a Juan de Acha e como avia gran volliçio en la dicha yglesia se salio y se fue y esto es lo que sabe e vido que paso y lo que responde a la pregunta". [...] "A la deçima pregunta dixo que este testigo no le hiço ninguna vaja el dicho Martin de Alviztur ni tal oyo e que si alguna vaja hizo en la dicha ovra queste testigo no la supo ni la oyo y esto dize y responde a esta pregunta". 
1555. Nuestro cantero había gastado mucho esfuerzo y recursos inútilmente y no pudo edificar la torre.

Juan de Acha, como Juan Martínez de Mutio, fue un magnífico representante de la generación siguiente a Martín Ruiz de Álbiz, San Juan de Arteaga y Juan de Rasines. Como estos, continuó por la senda del Tardogótico y realizó extraordinarios ejemplos de capillas centralizadas. Su situación económica inicial ayuda a valorar los descuidos que presenta su primera obra - por lo demás, asombrosa-. Más adelante, sus edificaciones se ejecutaron con un cuidado y virtuosismo admirables.

\section{ApÉNDice Documental}

1528, junio, 20

Tricio

Martín de Vergara, cantero vecino de Navarrete, y Juan de Acha, cantero vecino de la anteiglesia de San Miguel de Ispáster, contratan la realización de una capilla mayor nueva en la iglesia de San Miguel de Tricio.

ARCHV, Pl. Civiles, Fernando Alonso (F), C. 907.2.

En el lugar de Triçio barrio e beçindad de la cibdad de Najera e dentro de la yglesia de señor San Miguel del dicho lugar de Triçio a veynte dias del mes de junio año del nasçimiento de nuestro Salvador Jesuchristo de myll quinientos veynte e ocho años, este dicho dia en presencia de mi Juan Ybañes hescribano de sus magestades e de los testigos de yuso hescriptos estando ajuntados dentro della algunos de los benefiçiados de ella e conzejo a canpana tañyda segun que lo tienen de uso e de costunbre de se hayuntar para hazer e conzertar las cosas tocantes a la dicha yglesia e conzejo estando especial e nonbradamente los señores el liçenciado de la Canal arçediano e canonigo de la madre yglesia de Calahorra e Juan Perez e bachiller Pedro Perez cura e Pero Perez clerigos benefiçiados de la dicha yglesia por si e en nonbre de los otros benefiçiados ausentes e Juan de Hernan Martinez jurado e Pero Gomez de Isla e Andres Alonso e Juan Ybañes e Pero Martinez de la Plaza e Diego Martinez de la Plaza e Juan de Vaños e Juan Gomez e Martin Sanz de Guinea e Hernan Pardo, todos vecinos del dicho lugar e barrio de Triçio por sy y en nonbre de los otros veçinos del dicho lugar ausentes en la una parte e Martin de Bergara vecino de Nabarrete e Juan de Acha veçino de la anteyglesia de San Miguel de Ispaçer de la otra. Los dichos señores benefiçiados e los otros del dicho conzejo e los susodichos Martin de Vergara e 
Juan de Acha despues de aber mucho platicado e entendido sobre la capilla e obra que los dichos benefiçiados e conzejo daban haçer a los dichos Martin de Bergara e Juan de Hacha dixeron que se conzertaban e conçertaron en la forma e manera que se contiene en los capitulos que se siguen:

La capitulaçion y asiento que se tomo entre los clerigos benefiçiados de la yglesia de San Miguel e conçejo jurados e omes buenos del lugar de Triçio con Martin de Vergara e Juan de Hacha maestros de canteria para haçer la capilla mayor que nuebamente se a de hacer en la dicha yglesia es como se sigue:

La primera que la dicha capilla se da a los dichos Juan de Acha e Martin de Vergara ygualmente e por partes yguales e de la mysma manera ayan de hazer la obligaçion e dar las seguridades e fyanças lo qual de yuso mas se declarara.

I. Yten que la dicha capilla que se a de façer sea solamente de una nabe conforme la traça e muestra que los dichos maestros dexan firmada de sus nonbres en poder de los venefiçiados de la dicha yglesia y conçejo del dicho lugar e que no sea mas ancha ni mas angosta que la yglesia que agora esta fecha e que se de en el largo segun que esta en la muestra e conforme a la proporçion e medida que se requiere en la arte de geometria.

II. Yten que los dichos estribos que se han de haçer en el arco perpiaño de la capilla nueva se comiençen del ras de los formaletes de las capillas horneçinas viejas e a la parte de lo viejo venga e no salga mas que las paredes que agora estavan en la capilla nueva fechas e si mas grosor fuere menester que esto se le de hançia la capilla nueba de manera que vayan enbestidos en los cantones de las capillas horneçinas e los estribos suban lo que fuere menester e en ellos dexen los nasçimientos de los engarjamentos nesçesarios e provechosos a la obra de la dicha yglesia y en estos estribos reciban las capillas horneçinas viejas de manera que no aya ni reçiba daño alguno.

III. Yten que solamente se aya de abrir el arco del muro de medio que va donde aora esta el retablo e altar mayor e por do se abriere se aya de rebocar e reforçar esta pared a cada lado.

IIII. Yten que de tal manera abra en el dicho arco del muro de medio e los cantones de las capillas horneçinas biejas para envestir los estribos que todas tres capillas queden seguras para en todo tienpo e no ayan ni reçiban daño alguno ninguna dellas e si por bentura cayeren o algun daño rescibieren que sea costa e cargo de los dichos maestros para que lo ayan de haçer e remediar.

V. Yten que en esta capilla a la parte donde se diçe el hebangelio se aya de faser una sancristia en el lugar e de ancho e altura que pareçiere a los clerigos e a los dichos maestros. 
VI. Yten que dentro desta capilla agan los altares e gradas que fueren menester a paresçer de los benefiçiados e maestros.

VII. Yten que siguiendo la dicha muestra e traça paresçiere a los maestros que alguna cosa se ella se puede o debe mudar quitar añadir o haçer que sea provecho de la dicha obra e yglesia que esto lo ayan de primero ber muy bien e darlo a entender a los venefiçiados e concejo e se haga lo que por todos fuere deliberado y acordado.

VIII. Yten que antes que se abran los cantones de las capillas horneçinas para envestir los estribos que se a de haçer que se tase lo que vale el despojo que saldra de aquellos cantones e paredes e que lo que tasaren que vale se lo carguen e quenten a la tasaçion de la obra e que a los maestros se pague la costa de derrivar e apear e reparar las dichas capillas viejas e dello se aya respeto al tienpo de la tasaçion de la dicha capilla.

IX. Yten que la obra de la dicha capilla a de ser ansi de parte de dentro como de fuera a de ser labrada en la forma siguiente, las paredes y esquinas e relexes e tablamento todo a boca de hescoda e los pies derechos que sean de piedra franca de la de Buiçio o Santasensio labrados con su buena moldura e con sus buenos basamentos e capiteles muy bien hechos e que de la misma piedra sean los seis rincones de los ochabos de la capilla que las replisas labradas de molduras e follajeras sobre que se an de armar los enjarjamentos e que las jarças cruzerias e claves y el arco perpeano de toda esta capilla aya de ser de la dicha piedra de Buiçio o Santasensio e toda la otra obra de las paredes y estribos e de los prendientes para el casco de la capilla ayan de ser de la piedra de las Arenzanas o de Mahabe de los mejor que se hallare.

$X$. Yten que en la dicha capilla aya una ventana a la parte del sol a como esta en la muestra con su mainel e claraboya e moldura e si mas ventanas quisieren hacer que se vea al tienpo quando la obra fuere en el estado donde se deven haçer.

XI. Yten que la dicha capilla e toda la obra arriba dicha e que fuere nezesaria e provichosa ayan de dar fecha y acabada los dichos maestros dentro de siete años primeros que comienzen a correr desde oy dia de la fecha de la obligaçion.

XII. Yten que para que los dichos maestros ayan de haçer conplir todo lo arriba dicho dentro del dicho termino la yglesia e conçejo cunplan e hagan lo siguiente:

XIII. Lo uno que la dicha yglesia e conçejo ayan de traer e trayan en pie de la obra todo el ripio e arena e agua e cal que fuere menester para la dicha obra con tanto que los dichos maestros a su costa ayan de haçer la cal a su costa.

XIIII. Yten que los dichos maestros ayan de haçer la cal a su costa e que para ello la yglesia e conçejo les ganen lugar e liçençia para sacar la piedra de 
que se hoviere de hazer la cal e para costa e haçer la leña que sea menester para la quemar libre e francamente.

$X V$. Yten que la yglesia e conçejo ayan de ganar e ganen liçençia para que puedan sacar la piedra en las canteras de Buiçio o Santasensio libre e francamente e dar los caminos libres para la traer e pastos para sus ganados guardando pan e vino como a veçinos.

XVI. Yten que la yglesia e conçejo les ayan de dar al pie de la obra toda la madera e tabla e clavazon e maroma e sogas que fueren ansi para apear como para andamios e çinbras e otras cosas a la obra nezesarias e casa franca en que se puedan aposentar.

XVII. Yten que la yglesia e conçejo les ayan de dar aviertos los çimyentos a su costa como los maestros se los mandaren.

XVIII. Yten que la yglesia e conçejo a de conplir dar e pagar a los maestros en la forma siguiente:

XIX. Primeramente que la suma e cantidad de maravedis que de presente tiene la premiçia de la dicha yglesia hentrando en ella los frutos deste presente año de quinientos veynte e ocho deven cada año sesenta myll maravedis por los tercios del año den quatro en quatro meses veynte myll maravedis en cada terçio, e los veynte myll maravedis del primer terçio se les an de dar en comenzando a sacar piedra e haçer la cal comienzen los maestros por donde quisieren e danbos los maestros juntamente o al uno del consenstimiento del otro.

XX. Yten que acabada la suma e cantidad de lo que la dicha yglesia de presente tiene con los frutos del mesmo año como dicho es a los dichos maestros se aya de dar en cada año lo que la premiçia arentara guardando tres mil maravedis para las costas de la yglesia en cada año durante los dichos siete años los quales e la dicha obra acabados la dicha yglesia les aya de dar lo que rentare la dicha premiçia en cada año sacados los tres mil marabedis para las dichas costas de la yglesia hasta que sea acabada de pagar toda la suma e cantidad en que fuere tasada e averiguada la dicha obra e que en esto estan qualesquier derechos de sepulturas, deudas o mandas pertenescientes a la fabrica de la dicha yglesia y que el resto ayan de conplir los dichos maestros de sus bienes e aberes para conplir e acabar la dicha obra dentro de los dichos siete años.

XXI. Yten que aciendo el maestro dar el sacar de la piedra, hacer la cal abrir los cymientos e començar a hobrar sea e se comienze hasta el primer dia del mes de marzo primero benyente.

XXII. Yten que los dichos maestros juren de haçer buena obra a todo su saber e posibilidad e con los materiales e maniobras neçesarios e provechosos e le salarios suma e cantidad de maravedis que ovieren de aber por sus 
manos e trabajo e yndustria de la dicha capilla e obra con lo de confiar de tres, zinxo, siete o nueve personas de la yglesia e pueblo de Triçio los que los dichos maestros escogieren e quesieren para questos o la mayor parte dellos se ynformen de canteros maestro de çiençia e conçiençia e arte e sin sospecha sobre juramento que para ello hagan e de los mysmos maestro de la obra bueno o mala que abran hecho e de lo que mereçieren e los salarios e yndustrias e hobras de manos e ansi ynformados sobre juramento, e sus conçiençias e de aquellos de quien se ynformaren puedan arbitrar libremente añadir e quitar lo que les pareçiere e quisieren e por bien to / bieren de lo que hallaren por ynformaçion de los dichos maestros de la obra e de los otros maestros e canteros de quienes se ynformaren de manera que se haga confianza de las tales personas de la yglesia e conçejo e de sus buenas conçiençias de los que fueren escogidos e nonbrados por los dichos maestros açerca del salario que obieren de aver por las manos e labores e yndustria de haçer la dicha capilla e obra de las quales personas escoxidas e nonbradas no se debe creer que querran cargar sus conçiençias ni dar a perder a los dicho maestros por ayudar a la yglesia ni lo deben dejar.

XXIII. Yten los dichos maestros se an de obligar con sus personas e bienes e dar finazas bastantes sufiçientes e abonadas a contentamiento de la dicha yglesia e conçejo los quales se obliguen en forma cada uno por si e por el todo para haçer e cunplir todo lo arriba dicho e capitulado e cada cosa e parte dello e la dicha obligaçion hagan los maestros luego e las fianzas darlas han e las den dentro de un mes primero.

XXIIII. Yten que anvos los dichos maestros o al menos el uno dellos como ellos se conzertaren al menos ande e bea la obra que se haçe de contino e si por ventura entre ellos obiere alguna defirençia porque alguno dellos no viene ni esta haze ni cunple lo que conbiene e debe a la hobra que en este caso los beneficiados de la dicha yglesia e conzejo puedan ser juezes entre ellos para lo conçertar e no lo pudiendo conçertar puedan dar pena e quitar la obra al que les pareçiere que fuere en culpa o no andobiere derecho e probechoso en la obra e ny por tanto el dicho culpado ni sus fiadores no queden libres de la obligacion que tobieren hecha para el conplimyento de la dicha obra. /

XXV. Yten que los beneficiados de la yglesia e el dicho concejo ayan de dar una persona o dos a quien ayan recurso los maestros para todo lo que obieren menester e se obliguen al conplimiento e pago de todo lo arriba dicho e la yglesia e conçejo se obliguen de sacar a salbo e sin daño a las personas que a esto que dicho es se obligaren.

Para lo qual todo e cada cosa e parte dello segun e de la forma que de suso hes capitulado e asentado nos los dichos liçenciado de la Canal arçediano e Juan Perez clerigo e el bachiller Pedro Perez cura e Pedro Perez clerigo 
en nonbre de los otros bneficiados de la dicha yglesia obligamos los vienes e raices de la dicha yglesia especialmente e espresamente los de la capilla e fabrica della e nos los dichos Juan de Hernan Martines jurado e Pero Gomez de Yglesia e Juan Gomez e Juan de Baños e Andres Alonso e Juan Ybañes Herrero e Pero Martines de la Plaza e Diego Martines de la Plaça e Martin Sanz de Guinea e Hernan Pardo por nosotros e en voz e en nonbre del dicho conzejo e de los ausentes obligamos los propios e bienes del dicho concejo e nosotros los dichos Martyn de Bergara e Juan de Hacha maestro e canteros suso dichos anbos a dos juntamente e cada uno por si e por el todo renunçiando como renunciamos la lei de duobus rex devendi e la autentica presente hoq yta de fide jusoribus segun e como en ella se qontiene e para todo lo arriba dicho ansi a thener e guardar e conplir e pagar e dar las dichas fianças a contentamiento del dicho conzejo como de suso dicho es obligando nuestras personas e biene muebles e raizes donde quyer que los ayamos e tengamos e hesperamos aber e tener sometiendonos como nos sometemos a la juredicion hordinaria de la çibdad de Nagera anbas las dichas partes e cada uno de nos clerigos e seglares cada uno / por lo que le toca segun y como de suso dicho es damos todo nuestro poder conplido a todas e qualesquier justicias asi eclesiasticas como seglares de qualquier fuero e juredicion que sean ante quyen esta carta pareçiere e della fuere pedido entero conplimiento de justicia a cuya juredicion nos sometemos renunciando como renunciamos nuestro propio fuero juredicion e domeçilio para que por todo rigor e remedio del derecho nos conestringan e apremien a cada una de nos las dichas partes a los asi tener e guardar conplir e pagar realmente con efeto todo lo arria dicho e contenido e segun que de suso esta asentado e capitulado como si la hobiesen llebado por sentencia definitiva de juez conpetente e la tal sentencia fuese pasada en cosa juzgada e por nos e por cada uno de nos las dichas partes fuese loada e aprobada e consentida, sobre lo qual renunçiamos todas e queles quier leis fueros e derechos albalas e prebilegios hechos e por haçer a todos en general e cada uno en especial e las leis del derecho que diz que general renunciacion de leys que ome faga no non bala, que fue fecha e otorgada dia mes e año susodichos a lo qual fueron presentes por testigos Pero Sanz de Vieta vezino de Santurde e el bachiller Pabon e Martyn de Baños bordador e Pedro de Soba e Juanes de Baños clerigos veçinos e abitantes del dicho lugar de Triçio e por mayor fuerça algunos de los dichos benefiçiados e del dicho conzejo e testigos e los dichos Martin de Bergara e Juan de Acha firmaron aqui sus nonbres en el registro desto. Petrus licençiatus, Pero Gomez de Yglesia, Martin de Bergara, Juan de Acha por testigos el bachiller Pabon, Pero Ruiz / de Soba, Jhoanes de Baños clerigo, va entre renglones do diz como ellos se conzertaron al menos, bala y emendado e ysbala. E yo el sobredicho Juan Ybañes hescribano de sus magestades e su hescribano e no- 
tario publico en la su corte y en todos los sus reinos e señorios que presente fui en uno con los dichos testigos e de otorgamiento de las dichas partes lo fiçe hescrebir y escrebi segun que ante mi paso en estas seis hojas de papel con esta en que va este mi signo e de consentimiento de las partes como con esta por el auto que con la cabeça della ba e de pedimiento del dicho Juan de Hacha lo doi otra vez signado e por ende fiçe aqui este mi signo ques a todo testimonio de verdad. Juan Ybañes.

1540, diciembre, 10

Tricio

Juan Martínez de Mutio tasa la capilla mayor de la iglesia de San Miguel de Tricio que había realizado Juan de Acha. ARCHV, Pl. Civiles, Fernando Alonso (F), C. 907.2.

En el lugar de Triçio barrio e beçindad de la çibdad de Nagera a diez dias del mes de deçienbre año del naçimyento de nuestro salvador Jesuchristo de myll e quinientos e quarenta años en presenç̧ia de my el dicho Juan Ybañes hescribano de sus magestades e de los testigos de yuso hescritos en la plaça publica del dicho lugar estando ayuntados a conçejo clerigos e legos a son de canpana tañyda segun que lo tienen de uso e de costunbre para en semejantes casos e negoçios en espeçial estando presentes el bachiller Pero Perez cura benefiçiado de la yglesia de señor san Myguel del dicho lugar de Triçio e Martin Sanz de Guinea e Garçia Daroza jurados el bachiller Diego Hernandez Pero Perez Juan Geruepo Diego Martinez de la Plaça Pero Perez Juan de Prado Pero de Torreçilla Martin de Torreçilla Juan Martinez de Arenzana Pedro de Orozco Francisco de la Canal Juan de Logroño Sebastian de Anguiano Myguel de Hormilla / Pedro de Arençana Juan de Matute e otros muchos vezinos del dicho lugar por si e en nombre de todos los otros benefiçiados e del dicho conçejo ausentes e presentes de una parte, e Juan de Hacha maestro de canteria vezino de la çibdad de Logroño otra parte. Despues de aber platicado e entendido en el dicho conzejo entre las dichas partes sobre la tasaçion de la capilla del dicho lugar que los dichos benefiçiados e conzejo avian dado a haçer al dicho Juan de Hacha segun el contrato que por las dichas partes avia sydo otorgado ante el dicho hescribano el dicho Juan de Hacha abia hecho, e despues de aber platicado y entendido sobre ello la una parte con la otra estando presente Juan Martinez de Mutio cantero beçino e abitante en San Myllan de la Cogolla nonbrado por parte de los dichos benefiçiados e conçejo por escrito e firmado de su nonbre la tasaçion de la dicha capilla el tenor de la qual es como se sigue:

Tasaçion: Tasaçion del cantero nonbrado por el conçejo e yglesia: 
Visto por mi Juan Martinez de Mutio la obra que Juan de Hacha a hecho en la yglesia de señor san Myguel del barrio de Triçio e mirado cada cosa por si por menudo mirada asi la cruzeria e convados e arcos e pies derechos e baçamentos e capiteles e puerta de sancrestia e la sancrestia e los pies derechos de los ochabos de los capiteles arriba con sus jarjamentos e todos los formaletes y clabes e las piedras questan debaxo los basamentos e todos los jarjamentos que estan hechos para las obras que se an de haçer e toda la prendenteria e dobelaje e andamios e cinbrias e todos los estados que tiene / la obra ansi de los çimientos con ynformaçion que el señor cura e los del pueblo me dieron en la hondura dellas, e altar e gradas e luçir e color e pinçelar e todo lo que en toda la obra se debe myrar, digo que meresçe e bale toda la obra que el dicho Juan de Acha a hecho en la dicha yglesia seteçientos e nobenta e ocho myll e quinientos marabedis y en esto dicho que lo aclaro e doi por mi sentenciado su poder tengo para ello e lo firmo de mi nonbre e hare bueno con quyenquyera ofiçial que conmigo quyera entrar en quenta con un terçero que tengamos. Juan Martinez de Mutio.

\section{3}

1539, febrero, 20

Entrena

Juan de Acha contrata con el cabildo y concejo de Entrena la fábrica de una nueva iglesia parroquial.

ADZ, Apelaciones, C.349-7.

En la villa de Entrena a veynte dias del mes de hebrero año del señor de mill e quinientos e treynta e nueve años estando ajuntados los señores cabildo e conçejo e ayuntamiento de la villa de Entrena en su cabildo e ayuntamiento segun que lo an de uso e de costunbre de se ajuntar para semejantes casos en espeçial seyendo presentes los señores Martin Gonçalez de las Heras cura e Ruy Saenz de la Çervilla e Martin de Nalda e Diego de Coca cura e Pedro de Rabanera e Martin Garçia de Tejada clerigos e benefiçiados de la yglesia parroquial de la dicha villa e Pero Martinez de Verlanga alcalde hordinario de la dicha villa e Juan del Corral regidor e Francisco de Medrano e Diego de Robres e Juan de la Plaça e Martin de Carrança e Pedro de Torres todos vezinos de la dicha villa e los dichos Diego de Coca cura e Diego de Robres e Juan de Corral pro virtud del poder a ellos arriba contenido por el dicho cabildo e conçejo todos juntamente de un consentimiento e de una voluntad dixeron que por quanto la yglesia parroquial desta dicha villa esta para se caer e quanto mas va esta en mucho mas peligro e sobre ello an tomado paresçer con muchos maestros de canteria los quales los an dado e dizen que en ninguna manera se puede dexar de derribar la dicha yglesia e 
hazerse de nuevo porque no fue bien fundada y esta muy abierta e sobre ello an hecho su diligençia para vuscar maestro de çiençia e conçiençia e persona caudalosa para que haga la dicha yglesia y no an podido hallar ninguna que la haga con mejores condiçiones que cunplan a la dicha yglesia que Juan de Hacha cantero vezino de la ciudad de Logroño, por ende que ellos le davan e dieron al dicho Juan de Hacha cantero a hazer la dicha yglesia y obra della con las condiçiones e capitulos e preçio siguientes:

Primeramente que el dicho Juan de Hacha / aya de hazer la dicha obra de la dicha yglesia conforme a una traça que queda firmada de su nonbre e de los susodichos e de otras personas e que vaya con un caracol e con torre, la qual torre yguale con la obra de la dicha yglesia en lo alto y ancho como mejor visto le fuere a la dicha yglesia, con sus altares gradas que fueren neçesarias y ventanas y puertas todas las que fueren neçesarias e se le mandaren hazer e dada color e pinzelada la dicha obra a de llevar de piedra de Lamadriz todas las piedras de las bueltas asi de puertas como de ventanas como toda la pared de las esquinas [en otra copia: de los requibos] de la parte de adentro e con toda la capa de la dicha yglesia y de la sacristia que a de yr devaxo del altar mayor.

Yten que en la dicha obra a de aver dos personas que para ello la dicha yglesia nonbrara que esten por vedores que vean la obra que se haze e sobre ello puedan mandar lo que bieren que le cunple e mudar o enmendar e mandar hechar la cal que conviene a hazer a la dicha yglesia.

Yten que a de hazer la dicha obra dentro de diez años primeros siguientes los quales comiençan e corren del dia que el dicho Juan de Hacha diere fianças /

Yten que a de poner dos partes de la hazienda el dicho Juan de Hacha en la dicha yglesia mas que la dicha yglesia pusiere de tal manera que si la dicha yglesia le diere treynta mill maravedis el dicho Juan de Hacha sea obligado a poner sesenta mill maravedis de manera que en la dicha yglesia se hallen puestos noventa myll maravedis y ansi al respecto.

Yten que por el dicho ynterese y hazienda que ansi suya pusiere en hazer la dicha obra quando fuere apreçiada no se le pueda pedir ni contar a la dicha yglesia ningun interese ni provecho ni los maestros que la asi apreçiaren tengan respeto ninguno a dezir que a tenido su hazienda puesta ni envaraçada en probecho de la dicha yglesia sino que se tase e la tasaçion sea hecha como si de la propia hazienda de la yglesia se obiese hecho e hiziese.

Yten que cada e quando el dicho Juan de Hacha no cunpliese lo susodicho e no pusiere las dichas dos partes en la dicha yglesia segun dicho es que la dicha yglesia pueda traer e trayga ofiçiales a costa de la parte cayda e que bean y apreçien la dicha obra e si bieren que no cunple lo arriba contenido en quanto a la postura de la hazienda le puedan quitar e quiten la dicha obra 
e la den a hazer a su costa del dicho Juan de Hacha o de la dicha yglesia o como mas cunpla a la dicha yglesia o a quien bien visto le sea.

Para lo qual la dicha yglesia le a de dar en cada un año treynta mill maravedis al dicho Juan de Hacha pagados la meytad / para el dia de pasqua del Espiritu sancto de cada un año e la otra meytad para el dia de Sanctiago de cada un año los quales e no mas se le an de dar e pagar en cada un año como dicho es fasta en tanto que sea acabada de pagar toda la dicha obra de la dicha yglesia.

Yten se le a de dar el despojo de la yglesia que al presente residen despues que aya elegido la yglesia toda entera y este lebantada dos estados en alto fuera del suelo, o antes sy a la dicha yglesia le paresçiere el qual sea obligado a resçebir e tomar en quenta del pago prinçipal que montare toda la dicha obra de la dicha yglesia de tal manera que no se le quiten los dichos treynta mil maravedis de cada un año fasta en tanto que sea acabado de pagar la dicha obra, el qual dicho despojo se le dara apreçiado a vista de ofiçiales o vedores de çiençia e conçiençia nonbrados por cada una de las partes, o para que lo asiente por su parte esto a escoje de la dicha yglesia.

Yten que se le dara al dicho Juan de Hacha canteras e caminos e carretiles francos e sitios donde pudiere hazer caleras / e los montes de la villa para cortar maderas e cosas neçesarias para hazer el andamio de la dicha yglesia exçepto la dehesa de la dicha villa, y yerba franca guardando pan e vino donde quiera que sea aunque sea en la dehesa al tienpo que carreteare e quando no carreteare que la coma como los otros vezinos de la dicha villa.

Yten que la dicha yglesia y obra se le da a hazer a vista de ofiçiales de çiençia e de conçiençia sacados por anbas las dichas partes cada uno o dos personas e las que les paresçieren que cunplan para hazer la dicha tasaçion para que vista e apreçiada la dicha obra tasen e declaren e manden dar por ella todo aquello que justo fuere sobre juramento e sobre sus conçiençias el qual dicho pago a de ser segun dicho es.

Y el dicho Juan de Hacha cantero dixo que el resçebia e resçibio e tomava e tomo a hazer la dicha obra de la dicha yglesia con las condiçiones e capitulos e traça e preçios arriba declarados e que se obligaba e obligo con su persona e bienes muebles e rayzes avidos e por aver de hazer e cunplir todo lo arriba contenido en los dichos capitulos quel fuere obligado de hazer conforme a ellos. /

Y los dichos señores del cabildo y conçejo dixeron que obligaban e obligaron los bienes e propios e rentas de la dicha yglesia muebles e rayzes avidos e por aver de que la dicha yglesia pagara al dicho Juan de Hacha cantero los dichos treynta mil maravedis en cada un año a los dichos plazos fasta en tanto que sea acabada de pagar toda la dicha obra e que cunplira e manterna todo lo contenido e declarado en los dichos capitulos e condiçiones que la dicha yglesia fuere obligada de hazer e cunplir conforme a los dichos capitulos e de que no le quitaran al dicho Juan de Hacha la dicha yglesia ni obra della 
por mas ni por menos ni por el tanto cunpliendo el dicho Juan de Hacha lo susodicho para lo qual asi tener e guardar e cunplir e pagar e mantener anbas y dos las dichas partes por lo que a cada una dellas toca e atañe dieron todo su poder cunplido a todos e qualesquier juezes e justiçias asi eclesiasticos como seglares de quales quier çiudades e villas e lugares ante quien esta carta paresçiere e della fuere pedido cunplimiento de justiçia e para que ansi se lo hagan tener e guardar e cunplir e pagar e mantener haziendo e mandando hazer paga y hexecuçion en las dichas sus personas e bienes do quier que los hallaren e los bienes que por la dicha razon hexecutaren los vendan e rematen en publica almoneda o fuera della sin plazo ni termino alguno de los que fuero e derecho mandan e de los maravedis que balieren entregen e hagan pago a la parte que lo obiere de aver asi de las costas como del prin / çipal bien e a tan cunplidamente como si asi fuese juzgado e sentençiado por sentençia difinitiba de juez conpetente e la tal sentençia fuese pasada en cosa juzgada e por ellos e cada uno dellos fuese consentida e amologada sobre lo qual renunçiaron todas e queles quier leyes fueros e derechos canonicos e çebiles hordenamientos e usos e costunbres razones y hexeçiones y defensiones e todas ferias e mercados francos de pan e vino cojer e de conprar e de vender que no les balgan e otrosi renunçiaron la ley del derecho que dize que general renunçiaçion de leis que honbre haga que non bala. En testimonio de lo qual otorgaron esta carta e lo en ella contenido ante el presente escribano e testigos de yuso contenidos. Testigos que fueron presentes a lo susodicho Juan de Medrano e Diego del Ama e Diego Hernandez el moço e Juan de Verlanga vezinos de la dicha villa e lo firmaron de sus nonbres los siguientes por ellos e por los que no sabian a su ruego Martin Gonçalez de las Heras, Diego de Coca, Ruy Saenz de la Çerbilla, Pedro de Rabanera, Martin Garçia de Tejada, Martin de Carrança, Martin de Nalda, Juan de la Plaça, Pero Martinez de Verlanga, Pedro de Torres, Diego de Robres, Juan de Hacha, Francisco de Medrano e yo Juan Gonçalez de Paz escribano publico de sus magestades e vezino de la dicha villa de Entrena que en uno con los dichos testigos a todo lo susodicho presente fui e apedimiento de Juan de Hacha lo saque en esta publica forma que ante mi paso en fee de / lo qual hize este mi acostumbrado signo a tal en testimonio de verdad. Juan Gonçalez de Paz.

1551, septiembre, 6

Logroño

El mayordomo, diputados y parroquianos de la iglesia de Santiago escogen traza y condiciones para hacer una torre y portada y realizan el contrato tras público remate a candela.

ARCHV, Pl. Civiles, Varela (OLV), C. 941.8. 
En la muy noble e muy leal çiudad de Logroño dentro de la iglesia perroquial de seño Santiago de la dicha çiudad, domingo a seis dias del mes de setienbre año del señor de mill e quinientos e çinquenta y un años estando juntados dentro de la capilla de señor san Juan de la dicha iglesia los diputados e mayordomo della e algunos perroquianos que para el hefeto de yuso se ara mençion espeçialmente Pero Gomez de Varron e Fernando de Castro e Diego de la Parte diputados de la dicha iglesia de señor Santiago e Juan de Çarate mayordomo della y el dotor Rodrigo de Varron venefiçiado de la dicha yglesia e Juan Gonçalez e Pero Ybañes como personas diputados por la dicha iglesia aviendo puesto en mandado antes de agora poner heditos en los cantones publicos desta çiudad de Logroño para llamar canteros para les dar a hazer la torre e portalada que la dicha iglesia e clerigos e perroquianos della de sus faziendas e mandas quieren fazer en la dicha iglesia de señor Santiago e aviendo situado e mandado en los dichos heditos que todos los ofiçiales maestros canteros que quisieren tomar la dicha obras a hazer que viniesen para oy domingo dia con las trazas e posturas de la dicha obra e se le rematarian a quien en mejor preçio lo pusiese e ansi estando juntos paresçieron presentes maestre Juan de Acha cantero e maestre Juan de Landerrayn e maestre Martin de Landarrayn canteros e Bartolome de Arta cantero los quales dieron çiertas trazas para hazer la dicha portalada e torre delante de la puerta de la dicha iglesia e vistas por los dichos diputados e perroquianos escogieron e heligieron por mas conveniente para hazer la dicha obra la traza que dio Juan de Acha e ansi elegida y escogida los dichos diputados e mayordomo e perroquianos le mandaron al dicho Juan de Acha diese las condiçiones e posturas de la dicha traça para que sobre ello se ablase e platicase e para que quien mejor y en mejor preçio la pusiese fuese rematada la dicha obra e ansi luego el dicho maestre Juan de Acha cantero dio por escrito e firmado de su nonbre las dichas condiçiones e posturas e los susodichos las resçivieron la qual es en la forma e manera siguiente:

Santiago las dos traças que maestre Juan de Acha cantero vecino desta çiudad de Logroño da es en la forma e manera siguiente: /

Primeramente en la traça de la torre segun esta en el petipie a de tener de quadra de ezquina a esquina treynta y quatro pies por parte de fuera e a de salir la dicha traça veynte y dos pies fuera de las que agora tiene la dicha iglesia, e arriba ençima donde a de venir la portalada se a de hazer una capilla conforme a la plataforma que esta hecha en el pie de la dicha traça de la torre mas a de aver otra capilla debajo del suelo donde an de estar las canpanas y entre las dichas dos vobedas en par de las paredes viejas de la iglesia a de aver un aposiento para sancristan e canpanero entiendese que se a de hazer el suelo deste aposento de madera en lo demas la dicha torre conforme a la dicha traça a de tener de alto çiento e çinquenta pies asta la cornija de la 
quadra de la torre y el chapitel que esta debuxado ençima de la dicha torre se ara de madera cubierta con oja de Milan y a esto no se obliga el cantero en lo que toca al chapitel en lo demas a de hazer la dicha torre como dicho es de abajo arriba conforme a la dicha traza con dos luzeras donde el dicho aposento del canpanero.

Yten en quanto a la dicha portalada a de ser conforme a la traça que yo hize e firme de mi nonbre entiendese que a de tener de gueco la dicha portalada diez pies y a de llebar de alto al prinçipio de la buelta doze pies esa buelta redonda como esta en la dicha traza e todo lo demas contenido en la dicha traza conforme a este petipie que se aya de guiar e guardar como en ella esta devujado e traçado e se aya de hazer con muy vuena piedra fina destos terminos de Logroño e digo yo el dicho maestre Juan de Acha que la dicha portalada no se aya de hazer asta que le hechen una capilla o dos de cubierta a la dicha torre porque perderia el lustre la dicha portalada con las aguas e tormentas y en quanto al tienpo digo que a menester diez años para la hazer la dicha torre e portalada en quanto al preçio della digo que are la dicha torre e portalada segun dicho es por dos mill e quinientos ducados dandome en cada un año çiento e çinquenta ducados e lo cunplire ansi e lo firme de mi nonbre entiendese que la iglesia e perroquia a de poner la cal. Maestre Juan de Acha.

Ansi tomada e resçivida la dicha postura e condiçiones susodichas por los dichos diputados mayordomo e perroquianos de la dicha iglesia dixeron que a la tarde a la hora de la noche con candela se remataria como hera costunbre a lo qual fueron presentes por testigos Pedro de Salazar e Pero Perez e maestre Martin de Landarrayn vecinos y estantes en Logroño.

E despues de lo susodicho en la dicha çiudad de Logroño este dicho dia e mes e año susodichos algunos de los dichos diputados e mayordomos e perroquianos acordaron que no se hiçiese al presente la dicha portalada sino solamente la torre sin el chapitel e que pusiesen los dichos canteros postura de la torre. Testigos los dichos. /

E despues de lo susodicho en la dicha çiudad de Logroño el dicho dia a seis dias del mes de setienbre de mill e quinientos e çinquenta e un años maestre Juan de Acha cantero vecino desta çiudad de Logroño echando fuera la traça de la portalada e postura que oy dicho dia hizo sin el chapitel que en quanto a la dicha torre dixo que el ara la dicha torre en preçio de dos mill ducados conforme a la dicha traza e condiçiones en la dicha postura puesta e a los dichos tienpos e con las dichas pagas segun e de la manera que en la dicha postura se contiene e firmolo de su nonbre. Maestre Juan de Acha.

E despues de lo susodicho este dicho dia e mes e año susodichos estando delante las puertas de la dicha iglesia de señor Santiago mucha gente e los dichos señores diputados e mayordomo e mucha gente por voz de 
Pedro de Salvatierra pregonero publico en altas bozes por mandado de los dichos diputados e perroquianos e mayordomos susodichos pregono diçiendo quantos quisieren tomar la dicha torre a hazer conforme a la dicha traça e condiçiones susodichas sin la portalada e chapitel e quisieren hazer vaja la resçiviran e se a de rematar en quien la tuviere puesta al tienpo que se acavare una candela que estava ençendida y aquella a de ser remate acavada la dicha candela y ansi pregono la dicha postura en altas boçes primera e segunda vez a lo qual fueron presentes por testigos Pedro de Medina e Juan Benito e Graviel Ponçe clerigo e Juan de Ancheta vecinos de Logroño e otros.

E luego yncontinente paresçio presente maestre Juan de Landarrayn cantero e dixo que el ponia la dicha torre con las dichas condiçiones e posturas susodichas en mill e nuebeçientos e çinquenta ducados e ansi el dicho pregonero la torno a pregonar e pregono la dicha postura en altas boçes en la forma e manera susodicha testigos los dichos.

E luego yncontinente paresçio presente Bartolome de Arta cantero y dixo que el ponia e puso la dicha obra de la dicha torre con las condiçiones y en la forma susodicha e que el la aria en siete años por mil e siesçientos ducados, testigos los dichos.

E luego el dicho maestre Juan de Landarrayn puso la dicha obra en mill e quinientos e çinquenta ducados.

E luego yncontinente el dicho maestre Juan de Acha puso la dicha obra en mill e quinientos ducados con las dichas condiçiones testigos los dichos, e en mill e quatroçientos e çinquenta ducados maestre Juan de Landarrayn puso la dicha obra, testigos los dichos.

E luego Pedro de Medeçilla cantero puso la dicha obra diez ducados menos que son mill y quatroçientos y quarenta ducados y añadieron otro poco de candela e luego ya que se queria acavar la dicha candela Martin de Albiztur dixo diez ducados menos Martin de Albiztur / diez ducados menos e luego el dicho maestre Juan de Acha cantero dixo diez ducados menos y estava açendida ençima del cuchillo la candela ardiendo y el dicho Albiztur torno a deçir diez ducados menos diez menos y el dicho Juan de Acha tanvien dixo otra vez diez ducados menos y en estas ultimas posturas yo el dicho escribano no determino entre las palabras que la candela se murio mas de quando en todas ellas el dicho Albiztur estaba diçiendo diez ducados menos como dicho esta a lo qual fueron presentes por testigos Pedro de Medina e Pedro de Carrillo e mucha cantidad de gente e los dichos testigos e ansi quedaron diçiendo en mi queda el remate mas no sino en mi los susodichos, testigos los dichos.

E despues de lo susodicho en la dicha çiudad de Logroño en casa de mi el dicho escribano ablando sobre la dicha diferençia este dicho dia e mes e año susodichos en presençia de mi el dicho escribano e testigos de yuso 
escritos y en presençia de Pero Gomez de Varron y Hernando de Castro e Diego de la Parte diputados de la dicha iglesia e Juan de Çarate mayordomo de la dicha obra e fabrica paresçio presente maestre Juan de Landerrayn e maestre Martin de Landarrayn e dixeron que por mas claridad de la dicha diferençia que ellos por serviçio de Dios e hazer vien a la dicha iglesia que ellos ponian e pusieron con las dicha condiçiones e posturas e condiçiones susodichas en mill e quatroçientos ducados la dicha torre e obra susodicha sin el chapitel e sin la portalada como dicho esta e los dichos diputados e mayordomo resçivieron la dicha postura e lo pidieron por testimonio e declararon que el remate se entienda que se hiço e lo haçian e hiçieron en los dichos maestre Juan e maestre Martin de Landarrayn e ansi se la remataron la dicha obra en los susodichos en el dicho preçio e con las dichas condiçiones estando presentes por testigos Alonso del Espino e Martin de Varron e Juan Benito vecinos de la dicha çiudad de Logroño e lo firmaron de sus nonbres e porque el dicho maestre Juan dixo que no savia escrevir rogo a un testigo por el firmase. Pero Gomez de Varron, por testigo Martin de Varron, Diego de la Parte, Hernando de Castro maestre Martin de Landarrayn, Juan de Çarate.

E despues de lo susodicho en la dicha çiudad de Logroño a siete dias del dicho mes de setienbre del dicho año en presençia de mi el dicho escribano e testigos de yuso escritos paresçio presente Pedro de Medeçilla cantero vecino de Miruelo [Meruelo] avitante en esta çiudad de Logroño e dixo que el ponia e puso la dicha obra con las condiçiones susodichas en mill e tresçientos e noventa ducados e dara fianças en esta çiudad llanas e avonadas a lo qual fueron presentes por testigos Garçia Velez fontanero e Pedro de Medina y Hernando de Cayzedo vecinos de Logroño e firmolo de su nonbre en el registro. Pedro de Mereçilla paso ante mi Sevastian de Medina escribano.

Sin enbargo desto el dotor Varron e Pero Gomez de Varron e Diego de la Parte e Fernando de Castro y el mayordomo le hiçieron obligaçion y contrato obligandose con los vienes de la fabrica a los dichos maese Juan e maese Martin canteros.

1551, septiembre, 16

Logroño

Juan de Acha presenta una reclamación sobre la adjudicación de la torre de la iglesia de Santiago ante el licenciado Diego de Valdés, teniente de corregidor de Logroño.

ARCHV, Pl. Civiles, Varela (OLV), C. 941.8.

Magnifico señor maestre Juan de Hacha maestro cantero vezino desta çiudad como mejor aya lugar de derecho digo que queriendo los diputados 
y mayordomo de la yglesia de Santiago desta çiudad hazer una torre de calicanto en la dicha yglesia pusieron al almoneda la hobra de la dicha torre con la traza y condiçiones que yo di para la rematar de a candela segun constunbre ques que la obra queda rematada en el que haze y tiene hecha la mas baja postura al tienpo que se acaba la candela y el morirse la candela es avido por remate y es ansi que al tienpo que se murio y acabo la candela yo tenia hecha la mayor e mas probechosa vaja para la dicha yglesia y con esto quedo hecho el dicho remate e por ello me perteneze y es devida la dicha obra y siendo lo dicho ansi a venido a mi notiçia que algunos de los diputados particularmente despues del dicho remate an reçebido otra postura no mas probechosa que la mia y por vertud della an tornado a rematar la dicha obra en Juan de Landerra e maestre Martin no lo pudiendo hazer por lo que dicho es y que demas de lo dicho Martin de Alviztur se jata y alava que el hizo la mas vaja postura siendo como es ansi que no es maeso cantero ni pudo hazer postura y que fue la postrera y la mas vaja la mia por lo qual / se me deve y perteneze la dicha obra por ende a vuestra merced pido que declarando pertenezerme y serme devida la dicha obra me la mande dar e mande a los diputados y mayordomos de la dicha yglesia reçiban las fianças que me ofrezco a dar y me otorguen escritura en forma conforme a la traza y condiçiones de la dicha obra y mi hultima postura y reboque vuestra merced de quales quier otras posturas despues de la hecha y qualquier remate que se aya hecho en fabor de quales quier otros canteros poniendoles perpetuo silenzio sobre la dicha obra y mandando me la dar a mi como dicho es sobre lo qual pido justiçia e ynploro el conpetente ofiçio de vuestra merced e pido costas y testimonio. El liçenciado Espino.

\section{6}

1551, octubre, 17

Logroño

El escribano Martín de Albiztur, último licitador en el remate de la torre de Santiago, presenta contestación contradictoria a lo alegado por Juan de Acha ante el teniente de corregidor de Logroño.

ARCHV, Pl. Civiles, Varela (OLV), C. 941.8.

Magnifico señor, Martin de Albiztur en nonbre del mayordomo diputados y perroquianos de la yglesia de señor Santiago desta çiudad de Logroño e en nonbre de maestre Martin y de Juan de Landerran maestros canteros respondiendo a una demanda puesta por maestre Juan de Acha en que pide le sea hecha escritura de remate de la torre y postura que hizo y reboque la hescritura y remate en fabor mio y de mis parte hecha segun que en la dicha demanda se contiene su tenor repitido digo que vuestra merced no 
deve hazer ni prover cosa alguna de lo en contrario pedido por lo siguiente. Lo uno porque no se pide por parte vastante en tienpo ni en forma careze de los nezesario segun derecho y de verdadera relaçion niegola como en ella se contiene, lo otro porque el dicho Juan de Hacha no hizo postura ni baja que hultima fuese porque la hultima fue la que yo hize y ansi conforme a la postura se obiese juzgar e de ser y sera en mi favor como en persona que adquiera mayor derecho no obsta que diz que no sea maestro cantero porque la postura es de hazer a cada qual y la obra a los dichos maestros a los quales yo escojo para hazerla a los dichos mis partes de mas que en su nonbre y para / ellos yo hiziera la dicha vaxa y postura a los quales yo zedo qualquier derecho que yo tuviere, lo otro por la hescritura y vajas que obo no consta que fuese la postrera y asi ningun derecho adquirio el dicho Juan de Hacha ni se le debe ni tiene recurso alguno a la pedir, lo otro porque el dicho mayordomo e diputados pudieron hazer en qualquier tienpo el dicho remate en favor de mis partes pues tienen poder de la dicha perroquia y los dichos perrochianos la dan a hazer de sus propios bienes y hazienda y no de diezmos ni primiçias de la dicha yglesia y ansi tubieron libertad de dar a hazer la dicha obra a quien quisiesen como dueños y señores que son de sus haziendas, lo otro porque en caso de duda quando yncurren dos derechos o dos posturas y no se sabe qual sea la postrera se presume por aquel que en su favor despues se le hizo y otorgo y tiene la posesion y derecho y adquerido yn totuin como pareze de la dicha escritura y remate y ansi ba escluydo el dicho adverso que los dichos mis partes tienen la dicha obra remata y hecha escritura por ende a vuestra merced pido denyegue lo que en contrario se pide e aclare la dicha demanda no proçeder ni aver lugar y al dicho Juan de Hacha por no parte y le ponga perpetuo silenzio asolbiendome y dandome por libre y a los dichos mis partes sobre que pido justiçia costas y testimonio y en lo nezesario su ofiçio ynploro. El liçençiado Medina.

\section{Bibliografía}

ÁlVAREZ CLAVIJO, Mำ Teresa, “El convento de Madre de Dios y la casa de los Enciso, en Logroño (La Rioja)", Berceo, 140 (2001), pp. 175-212. ÁLVAREZ CLAVIJO, Ma Teresa, Las artes en la Iglesia Imperial de Santa María de Palacio de Logroño (siglos XII al XVII), Logroño, IER, 1995.

ÁLVAREZ CLAVIJO, Mํㅡㄹ Teresa, Logroño en el siglo XVI: arquitectura y urbanismo, Logroño, IER, 2003.

ARRAZOLA ECHEVERRÍA, Maㅡ Asunción, Renacimiento en Guipúzcoa. Tomo I. Arquitectura, San Sebastián, Diputación Foral de Guipúzcoa, 1988.

BARRIO LOZA, José Ángel y MOYA VALGAÑÓN, José Gabriel, “El modo vasco de producción arquitectónica en los siglos XVI-XVIII", Kobie, 10 
(1980), pp. 283-369.

BARRIO LOZA, José Ángel y MOYA VALGAÑÓN, José Gabriel, “Los canteros vizcaínos (1500-1800). Diccionario biográfico", Kobie, 11 (1981), pp. 173-282.

BARRON GARCÍA, Aurelio Á., "Bóvedas con figuras de estrellas y combados del Tardogótico en La Rioja", Turiaso, XXI (2012-2013), pp. 219268.

BARRÓN GARCÍA, Aurelio Á., “La galilea y el panteón real de Nájera: Juan Martínez de Mutio, Alonso Gallego y Arnao de Bruselas", BSAA arte, 84 (2018), en prensa.

BARRÓN GARCÍA, Aurelio Á., “La obra del arquitecto tardogótico Juan Pérez de Solarte en Anguiano y Nájera (La Rioja)", Berceo, 174 (2018), pp. 65-120.

BARRON GARCÍA, Aurelio Á., “Martín Ruiz de Álbiz y San Juan de Arteaga, arquitectos de la catedral de Santa María la Redonda en Logroño (1523-1529)", Goya, 353 (2015), pp. 263-287.

BARRÓN GARCÍA, Aurelio Á., "Primeras obras en La Rioja del arquitecto Juan de Rasines, 1469-1542", Boletín del Museo e Instituto Camón Aznar (BMICA), 110 (2012), pp. 7-84.

BARRÓN GARCÍA, Aurelio A., "Sobre las obras de madurez del arquitecto tardogótico Juan de Rasines", Berceo, 162 (2012), pp. 228-257.

CADIÑANOS BARDECI, Inocencio, "El Monasterio de La Estrella y Navarrete el Mudo", Boletín de la Real Academia de Bellas Artes de San Fernando, 63 (1986), pp. 261-301.

CALATAYUD FERNANDEZ, Elena, Arquitectura religiosa en La Rioja Baja: Calahorra y su entorno (1500-1650), Logroño, Colegio Oficial de Aparejadores y Arquitectos técnicos de La Rioja, 1991.

GOICOECHEA, Cesáreo, "Artistas y artífices riojanos (Contribución a la Historia de las Bellas Artes en La Rioja)", Berceo, 57 (1960), pp. 405-446.

LECUONA, Manuel de, "La catedral de Calahorra (notas histórico-arqueológicas)", Berceo, 2 (1947), pp. 63-110.

LECUONA, Manuel de, "La parroquia de Santiago de Calahorra. Breves notas históricas", Berceo, 24-25 (1952), pp. 469-490 y 601-634.

LÓPEZ FERNÁNDEZ, Adolfo, La iglesia de San Bartolomé de Logroño. Historia de la conservación del monumento en el siglo XIX, Logroño, IER, 2103.

MATEOS GIL, Ana Jesús, La iglesia de Santiago el Real de Calahorra. 1500-1800, Logroño, IER, 1991.

MOYA VALGAÑÓN, José Gabriel (dir), Inventario artístico de Logroño y su provincia. Tomo II (Cenicero-Montalbo de Cameros), Madrid, Centro Nacional de Información Artística, Arqueológica y Etnológica, 1976.

MOYA VALGAÑÓN, José Gabriel, "Manifestaciones artísticas en Logroño", 
en Historia de la ciudad de Logroño. Tomo II. Edad Media, Zaragoza, Ibercaja - Ayuntamiento de Logroño - Universidad de La Rioja, 1994.

MOYA VALGAÑÓN, José Gabriel, Arquitectura religiosa del siglo XVI en La Rioja Alta, Logroño, Instituto de Estudios Riojanos (IER), 1980.

PASTOR ABÁIGAR, Víctor, "Juan de Landerrain. Un maestro cantero guipuzcoano en Navarra", Príncipe de Viana, 201 (1994), pp. 89-115.

PORTILLA VITORIA, Micaela J., Catálogo monumental diócesis de Vitoria. T. V. La Llanada alavesa oriental, Vitoria, Obra Cultural de la Caja de Ahorros Municipal de Vitoria, 1982.

ROMERO MEDINA, Raúl, “Un cantero tardogótico de posible ascendencia cántabra en Castilla: maestre Pero de Cubillas (1496-1525)", Laboratorio de Arte. Revista del Departamento de Historia del Arte, 19 (2006), pp. 49-66.

SAN MARTÍN ASCACÍBAR, Luis, La actividad artística en La Rioja durante el siglo XVI, Logroño, IER, 2005. 
